\title{
Initial MAR Assessments to Access the Impact of Al-dissolution on DWPF Operating Windows
}

J.D. Newell

T.B. Edwards

D.K. Peeler

December 2007

Process Science and Engineering Section Savannah River National Laboratory Aiken, SC 29808 
WSRC-STI-2007-00688

Revision 0

\section{DISCLAIMER}

This report was prepared by Washington Savannah River Company (WSRC) for the United States Department of Energy under Contract No. DE-AC09-96SR18500 and is an account of work performed under that contract. Neither the United States Department of Energy, nor WSRC, nor any of their employees makes any warranty, expressed or implied, or assumes any legal liability or responsibility for the accuracy, completeness, or usefulness, of any information, apparatus, or product or process disclosed herein or represents that its use will not infringe privately owned rights. Reference herein to any specific commercial product, process, or service by trademark, name, manufacturer or otherwise does not necessarily constitute or imply endorsement, recommendation, or favoring of same by WSRC or by the United States Government or any agency thereof. The views and opinions of the authors expressed herein do not necessarily state or reflect those of the United States Government or any agency thereof.

\section{Printed in the United States of America \\ Prepared For \\ U.S. Department of Energy}

The Savannah River National Laboratory is operated for the U.S. Department of Energy by Washington Savannah River Company. 


\section{Initial MAR Assessments to Access the Impact of Al-dissolution on DWPF Operating Windows}

J.D. Newell

T.B. Edwards

D.K. Peeler

December 2007

Process Science and Engineering Section Savannah River National Laboratory Aiken, SC 29808

Prepared for the U.S. Department of Energy Under Contract Number DEAC09-96SR18500

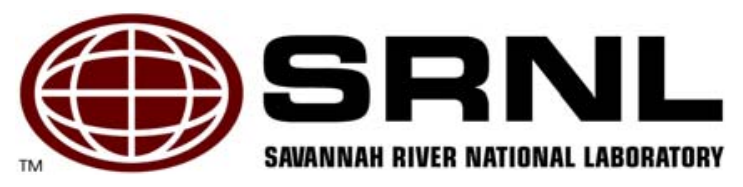


WSRC-STI-2007-00688

Revision 0

\section{REVIEWS AND APPROVALS}

\section{AUTHORS:}

J.D. Newell, Process Science and Engineering Section

Date

T.B. Edwards, Statistical Consulting Section

Date

D.K. Peeler, Process Science and Engineering Section

Date

\section{TECHNICAL REVIEWER:}

K.M. Fox, Process Science and Engineering

Date

\section{APPROVERS:}

C.C. Herman, Manager, Process Engineering Technology Group

Date

R.E. Edwards, Manager, Process Science and Engineering

Date

J. Stuberfield, Project Owner - Sludge Mass Reduction Program

Date

Technology Development and Tank Closure - Liquid Waste

P.C. Suggs, DOE - SRS/AMWDP

Date

Technology Development Lead 
WSRC-STI-2007-00688

Revision 0

\section{EXECUTIVE SUMMARY}

SRNL was tasked to provide an assessment of the downstream impacts (or lack thereof) to DWPF of decisions regarding the implementation of Al-dissolution to support sludge mass reduction and processing. Based on future sludge batch compositional projections, assessments have been made with respect to the ability to maintain comparable projected operating windows for sludges with high temperature Al-dissolution and without Al-dissolution.

In general, paper study assessments indicated that most of the future sludge batches (twelve with and fourteen without high temperature Al-dissolution) had multiple frits available that yielded relatively large operating windows. The projected operating windows were defined by the waste loading (WL) interval over which glasses were classified as acceptable based on current process control models and their related constraints. Although multiple frits were identified, using a 17point width as a general guide for a reasonable operating window (e.g., $25-41 \% \mathrm{WL}$ ), there generally appeared to be more flexibility in frit selection for the without Al-dissolution flowsheets. This larger frit compositional platform could allow frit development efforts to make more significant adjustments to melt rate.

However, based on the general observations of the paper study, there is essentially no clear distinction between the two options with which to drive a decision to implement Al-dissolution. That is, comparable operating windows can be achieved through the frit development and selection process for either process. One could interpret this general summary statement to indicate: given frit development efforts can compensate for the different pretreatment strategies yielding equivalent operating windows or maximum WL targets, the lower sludge mass as a result of Al-dissolution would obviously result in reducing the number of cans produced at DWPF. Although the basic mathematics is technically sound, other factors need to be considered including facility operating times or mission life for the Tank Farm, DWPF and Saltstone.

To address some of these questions, candidate frit compositions have been selected to assess melt rate as a function of waste loading for the glass systems representing future sludge batches with and without $\mathrm{Al}$ dissolution. The frit selection process was driven by reviewing compositional trends that have historically influenced melt rate as well as identifying systems with relatively large operating windows. With respect to the identification of sludge batches to support the melt rate testing, average compositions representing with and without Al-dissolution "clusters" were developed using a statistical grouping routine.

Ultimately, five frits were identified for each average "cluster" composition. Melt rate assessments will be performed as a function of waste loading for the five frits selected. The data obtained from the experimental melt rate program can be used in combination with actual DWPF processing data to provide valuable insight into the waste throughput potentials for both flowsheets. 


\section{TABLE OF CONTENTS}

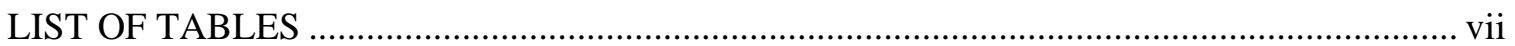

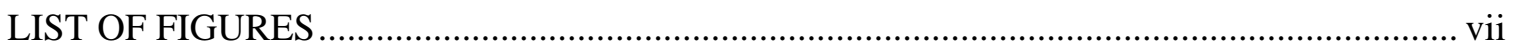

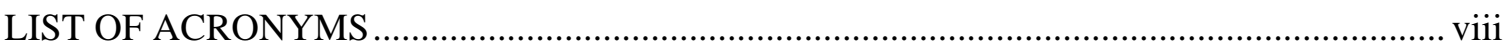

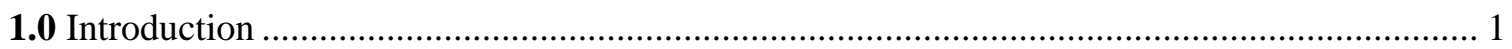

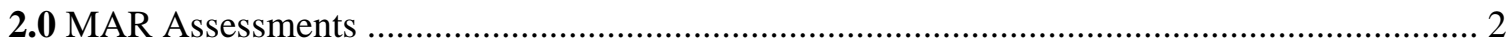

2.1 Project Sludge Compositions ............................................................................. 3

2.2 Candidate Frit Compositions to Support MAR Assessments .......................................... 3

2.3 Nominal Stage Assessments and Acceptance Criteria............................................... 4

3.0 MAR Assessment Results - Paper Study.................................................................. 5

4.0 Melt Rate Versus Waste Loading: A Historical Review .................................................. 9

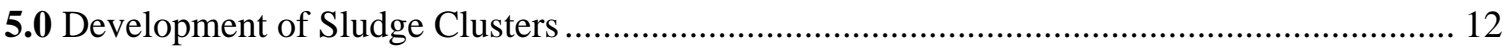

6.0 Selection of Candidate Frit Compositions for Melt Rate Testing .................................... 15

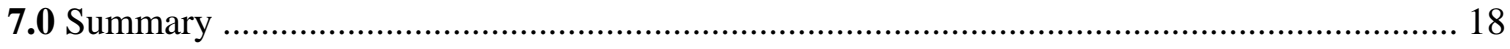

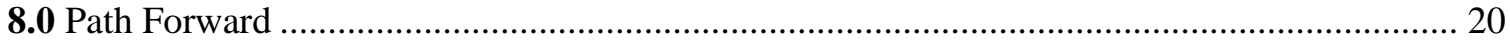

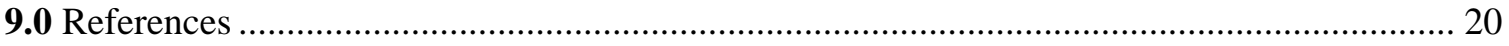

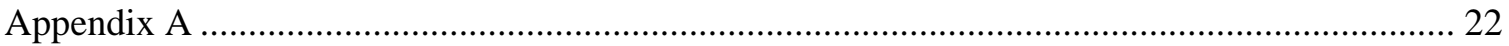




\section{LIST OF TABLES}

Table 3-1. Number of Frits Out of the Candidate Set of 1755 that Provide a ............................... 7

Table 5-1. Components Used to Cluster Sludge Compositions. .................................................. 12

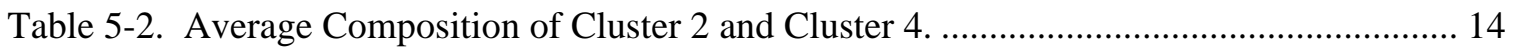

Table 5-3. Number of Frits that Provide Projecting Operating Windows of the Indicated Width

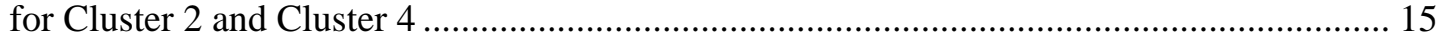

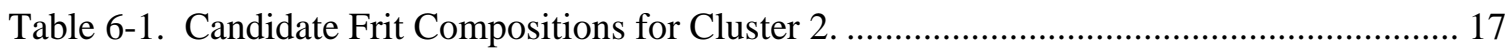

Table 6-2. Candidate Frit Compositions for Cluster 4. ............................................................... 18

\section{LIST OF FIGURES}

Figure 2-1. Compositional Grid of the 1755 Frits Used to Support the MAR Assessments.......... 4

Figure 4-1. Historical Trend Between Melt Rate and Waste Loading. ....................................... 10

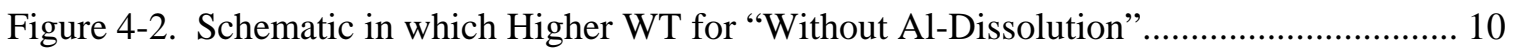

Figure 4-3. Schematic in which Higher WT for "Without Al-Dissolution”.................................. 11

Figure 5-1. Schematic of Clusters Identified Using JMP ......................................................... 13

Figure 6-1. Candidate Frit Compositions for Cluster 2.......................................................... 16

Figure 6-2. Candidate Frit Compositions for Cluster 4............................................................. 17 


\section{LIST OF ACRONYMS}

$\begin{array}{ll}\text { Al } & \text { Aluminum } \\ \text { CPC } & \text { Chemical Process Cell } \\ \text { DOE } & \text { Department of Energy } \\ \text { DWPF } & \text { Defense Waste Processing Facility } \\ \text { EM } & \text { Environmental Management } \\ \text { LTAD } & \text { Low Temperature Aluminum Dissolution } \\ \text { LWO } & \text { Liquid Waste Organization } \\ \text { MAR } & \text { Measurement Acceptability Region } \\ \text { NL [B] } & \text { Normalized Leachate for Boron } \\ \text { PAR } & \text { Property Acceptability Region } \\ \text { PCCS } & \text { Product Composition Control System } \\ \text { PCT } & \text { Product Consistency Test } \\ \text { QA } & \text { Quality Assurance } \\ \text { SB } & \text { Sludge Batch } \\ \text { SRAT } & \text { Sludge Receipt and Adjustment Tank } \\ \text { SRNL } & \text { Savannah River National Laboratory } \\ \text { T } & \text { Liquidus Temperature } \\ \eta & \text { Viscosity } \\ \text { WALD } & \text { With Al-Dissolution } \\ \text { WL } & \text { Waste Loading (weight percent) } \\ \text { WOALD } & \text { Without Al-Dissolution } \\ \text { WT } & \text { Waste Throughput }\end{array}$


WSRC-STI-2007-00688

Revision 0

\subsection{Introduction}

Implementation of the aluminum (Al)-dissolution process for specific sludge batches is being considered by the Liquid Waste Organization (LWO) primarily for sludge mass reduction. The premise being a reduction in the amount of insoluble solids in the sludge going to the Defense Waste Processing Facility (DWPF) should translate into a decrease in the number of high-level waste canisters produced. However, implementation does not come without technical issues to address. These include but are not limited to:

(1) the effectiveness of the Al-dissolution process (i.e., the amount of $\mathrm{Al}$ that will be removed),

(2) possible rheological issues associated with the sludge after Al-removal [1], which could hamper sludge transfer and/or melter processing and preparation in the Tank Farm,

(3) impacts to downstream processes [2] such as Saltstone (which will process the Al-rich supernate) and DWPF,

(4) impacts to glass formulation efforts (in particular, the ability of frit development efforts to compensate for the sludge compositional changes), and

(5) impacts to melt rate or waste throughput (i.e., the amount of waste being processed per unit time) for the DWPF.

If Al-dissolution is not implemented or low temperature Al-dissolution (LTAD) is desired over the higher temperature option, glass formulation efforts will have to accommodate higher $\mathrm{Al}_{2} \mathrm{O}_{3}$ concentrations (assuming similar waste loadings are targeted). Although projected $\mathrm{Al}_{2} \mathrm{O}_{3}$ concentrations in glass do not appear to approach solubility limits for DWPF-type glasses [3], higher targeted waste loadings or significant improvements in melt rate would be required to offset the increased sludge mass. It is possible that significant melt rate differences could exist between a sludge composition having undergone Al-dissolution relative to one that has not. A primary driver in defining that possible difference is the ability of frit development efforts to compensate for the higher or lower $\mathrm{Al}_{2} \mathrm{O}_{3}$ content while maintaining access to waste loadings of interest and meeting related process control criteria. Recently, the Savannah River National Laboratory (SRNL) has been able to maintain reasonable waste loadings and melt rates for glass produced from a relatively high $\mathrm{Al}_{2} \mathrm{O}_{3}$-based sludge (Sludge Batch $4-\mathrm{SB} 4$ ) in DWPF as a result of frit optimization efforts. SRNL has also been able to eliminate the formation of nepheline brought on by the high levels of both aluminum and sodium associated with HM feeds through the implementation of a nepheline discriminator and the use of high $\mathrm{B}_{2} \mathrm{O}_{3}$-based frits. These facts, combined with the need to support sludge mass reduction efforts to address uncertainties in Al-dissolution effectiveness and the need to mitigate possible rheology issues, such as those observed during SB4 and Sludge Batch 5 (SB5) testing [4], have resulted in Al-dissolution options being re-evaluated for HM sludges for future operations.

The Department of Energy (DOE) - Office of Environmental Management (EM) has requested an assessment of the impacts of the Al-dissolution process on DWPF operations. As outlined in the Task Technical and Quality Assurance (QA) Plan [5], there are three major task activities associated with this program: (1) assessing projected operating windows for future sludge batches with and without high temperature Al-dissolution (which includes frit development efforts for higher $\mathrm{Al}_{2} \mathrm{O}_{3}$ based glasses), (2) evaluating melt rate for specific frit - sludge combinations of interest, and (3) addressing Chemical Process Cell (CPC) impacts. This report focuses on the impacts of the Al-dissolution process relative to the ability of frit development efforts to provide reasonable projected operating windows for DWPF. More specifically, current Product Composition Control System (PCCS) models and their associated constraints or limits [6] will be 
utilized to assess projected operating windows for future DWPF sludge batches (with and without Al-dissolution). The primary objective of this task is to determine if there are technical limitations associated with specific sludge batches (either with or without Al-dissolution) which, if identified, could provide critical feedback to the LWO as they assess the downstream impacts and make critical decisions regarding the implementation of Al-dissolution. A secondary objective of this report is to identify candidate frits that could be utilized to assess melt rate for both flowsheet options. The candidate frits will be selected based on the ability to provide relatively large operating windows and to support compositional trends which have been demonstrated to improve melt rate based on historical DWPF processing data from SB3 and SB4. A subsequent report will summarize the melt rate evaluations for the candidate frits.

As previously mentioned, there are other potential impacts of Al-dissolution that must be considered when making decisions regarding Al-dissolution implementation. One critical technical issue is the ability or need to adjust the rheology of the sludge to meet transfer requirements (flow characteristics) or the opportunity to pursue other tank washing and/or blending strategies to maximize waste throughput. Recent results with SB4 and SB5 have seen significant changes to the sludge rheology as a function of washing [7] and Al-removal [1]. In general, the sludge became thicker with the implementation of Al-dissolution and with increased washing using the low aluminum feed. These aspects are not easily predicted and need to be assessed through experimental testing. Given that Al-dissolution will add a substantial amount of caustic to the system and assuming the same wash end-points for sodium ( $\mathrm{Na}$ ) molarity are targeted, the anion balance will shift from being primarily nitrite-nitrate to being primarily hydroxide in the washed sludge. This will potentially impact the acid additions at DWPF. As mentioned in the Technical Task and QA plan, CPC simulations to determine the impact of the change to anion concentrations will also be evaluated with simulants as an integral part of this program (activity 3 as listed above). Although a critical input into the decision making process, the details associated with the CPC testing and results will be documented elsewhere.

The integrated results of these three programmatic activities will provide some of the required inputs to support a cost-benefit analysis of the Al-dissolution process. Additional inputs can be achieved as one balances the obvious positive impact of mass reduction on the total number of canisters produced with the ability of the glass formulation team to develop frits that are capable of handling relatively high concentrations of $\mathrm{Al}_{2} \mathrm{O}_{3}$ while maintaining a relatively high melt rate. This could ultimately lead to higher waste throughputs for DWPF or off-set costs and risks associated with full implementation of Al-dissolution. Additional insights into the Al-dissolution implementation decision could be gained by assessing processing of SB5 (in which low temperature Al-dissolution was performed) through DWPF. Again, the focus of this report is on the paper study assessments associated with future sludge batches and the impact of high temperature Al-dissolution on the projected operating windows.

\subsection{MAR Assessments}

In order to perform the Measurement Acceptability Region (MAR) assessments which lead to a determination of projected operating windows, two critical inputs are required: (1) projected sludge compositions and (2) candidate frit compositions. Given these two inputs, glass compositional regions of interest can be defined and evaluated against existing PCCS [6] criteria to establish projected operating windows for the glass systems of interest. Projected operating windows are defined by the waste loading (WL) interval over which glasses are classified as acceptable based on the current models and algorithms within PCCS and their associated acceptance criteria. The following sections will provide the nominal sludge projections, the 
technical basis for the frit compositional region of interest, and a high-level summary of the MAR assessment criteria utilized.

\subsection{Project Sludge Compositions}

Tables A1 and A2 in Appendix A provide listings of the sludge projections with and without, respectively, high-temperature aluminum dissolution as reported by LWO [8]. Twelve sludge batches were identified based on implementation of high temperature Al-dissolution, while fourteen sludge batches represent the without Al-dissolution flowsheet.

\subsection{Candidate Frit Compositions to Support MAR Assessments}

One of the more significant challenges of this task was to define or identify candidate frit compositions for the 26 nominal sludge compositions. Typically, glass formulation efforts are focused on 2 - 3 nominal sludge compositions based on different washing or blending strategies for a specific sludge batch. In this task, variations in washing or blending strategies are not considered, but 26 future sludge batches are represented that present a unique challenge to the frit development team. The unique challenge is to provide each sludge option with a diversity of frit compositions that yield acceptable projected operating windows and offer experimental options for investigating melt rate. Conceptually, the frit development team tried to balance the development of a sufficiently large frit grid to provide each sludge option an opportunity to demonstrate relatively large operating windows against the possibility that the grid intervals may be too coarse (or not include other critical frit components). This approach could lead to failure to identify any optimal frits for a specific sludge batch.

Figure 2-1 provides an overview, in the form of histograms, of the array of frits that was considered during this evaluation. As seen in Figure 2-1, there were 15 levels for $\mathrm{B}_{2} \mathrm{O}_{3}, 9$ for $\mathrm{Li}_{2} \mathrm{O}$, and 13 for $\mathrm{Na}_{2} \mathrm{O}$, leading to $15 \times 9 \times 13=1755$ frit candidates that were used in the MAR evaluations. Note that $\mathrm{SiO}_{2}$ concentration was the fourth component making up the remainder of each frit so that the sum of the components was 100 weight percent (wt \%). None of these frits should be considered as necessarily "optimal" for any of the sludge compositions of this study. For example, other possible frit components such as $\mathrm{Fe}_{2} \mathrm{O}_{3}, \mathrm{MgO}, \mathrm{CaO}$, or $\mathrm{ZrO}_{2}$ were not added to the grid. These components could have a positive impact on the projected operating windows for some of the projected sludge compositions or improve melt rate. In addition, the ranges (minimum and maximum values) for the four major components may not be optimal. However, the compositional grid developed (both components added and ranges used) does cover the historical frit region of interest for DWPF operation (i.e., Frit 320 for SB2, Frit 418 for SB3, and Frit 510 for SB4), and it is believed to provide a reasonable basis for meeting the programmatic objectives of this task. 


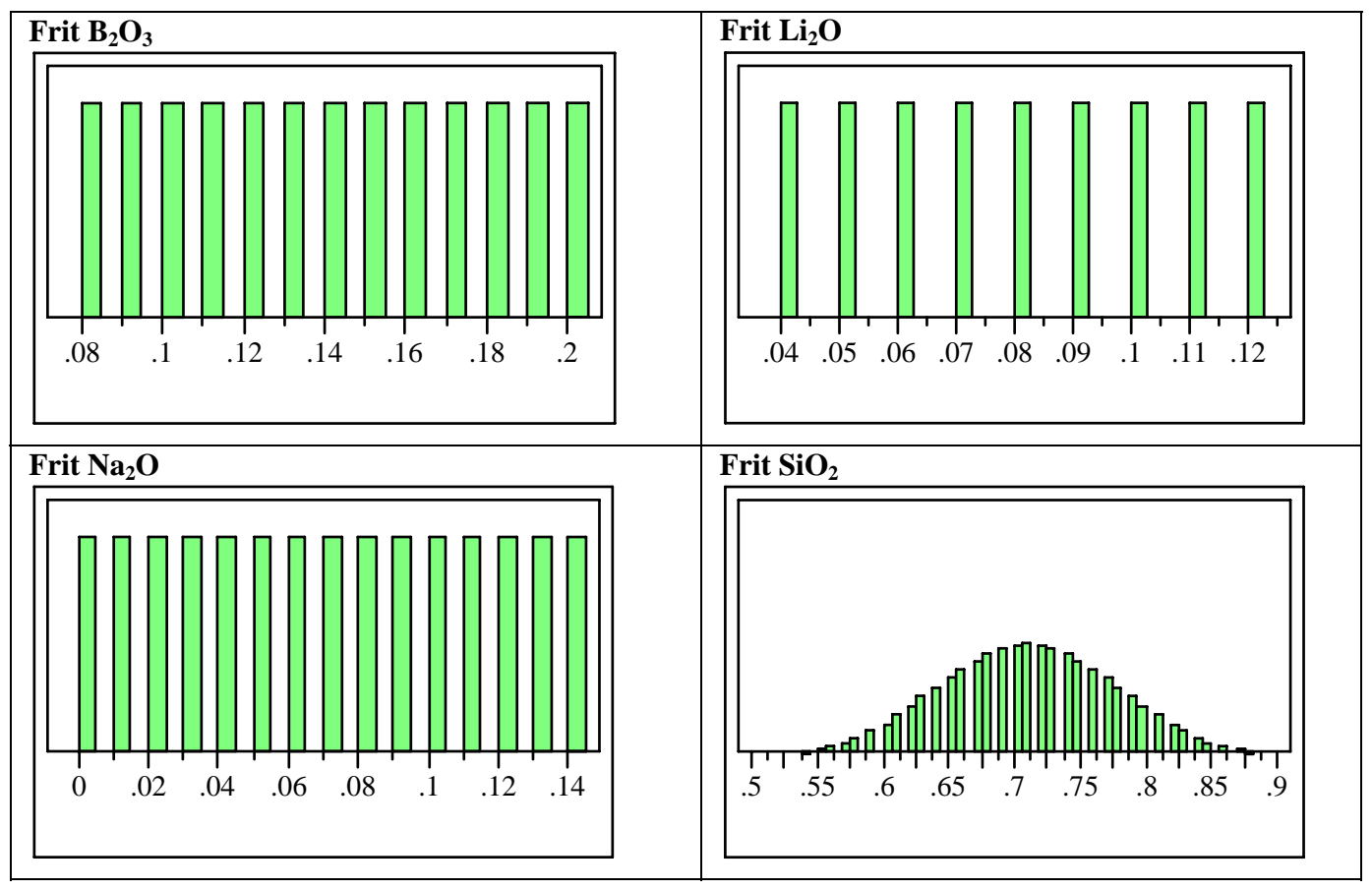

Figure 2-1. Compositional Grid of the 1755 Frits Used to Support the MAR Assessments ${ }^{\mathrm{a}}$.

\subsection{Nominal Stage Assessments and Acceptance Criteria}

The objective of the MAR assessment was not to identify optimal frits, but to ensure that frits can be identified that lead, based upon MAR predictions, to reasonably attractive WL intervals for DWPF operations. Not finding such intervals for most of the sludge compositions associated with high-temperature aluminum dissolution (WALD), or finding very few frit compositions that lead to such intervals, would suggest that the pursuit of that option may be problematic for SRNL's frit development team. If few attractive operating windows are predicted for the sludge compositions projected without high-temperature aluminum dissolution (WOALD), then that option would be flagged as potentially problematic for frit development. If several frits can be identified for most of the projected sludge compositions for both flowsheet options (WALD and WOALD), then the study would offer little or no limitation to the pursuit of either flowsheet option. Such an outcome would also serve as the basis for identifying a family of frits for each sludge composition that would be available for consideration as part of the path forward for the melt rate (experimental) and CPC portions of this study.

Therefore, the two primary metrics to be used in the MAR assessment evaluations are: (1) the projected operating window size and (2) the number of frits that provide relatively large operating windows. The initial metric, projected operating window size, is relatively self-explanatory with the exception of what criteria will be used to define a reasonably wide window. Based on historical Nominal Stage assessments, the frit development team typically defines a $17-20$ point wide window as reasonable. This width would encompass (at a minimum) a 25 to a low 40s WL

\footnotetext{
a The compositional grids show the mass fractions of the frit elements versus the proportion of the frits that had the level of the frit component. For $\mathrm{B}_{2} \mathrm{O}_{3}, \mathrm{Li}_{2} \mathrm{O}$, and $\mathrm{Na}_{2} \mathrm{O}$ the bars are equal in height because there are an equal number of frits with that level of the component. $\mathrm{SiO}_{2}$ appears as a bell shape due to the fact that silica had a variable concentration in order to bring the total mass fraction to 1
} 
interval over which glasses for a specific frit - sludge option would be deemed acceptable. This width also provides flexibility if one were to assess the potential impact of sludge compositional variation on the projected operating windows. This latter assessment is referred to as a Variation Stage assessment, which is not utilized in this task. The second metric, the number of frits, provides insight into the potential for frit development efforts to influence melt rate through frit compositional changes or to adapt to some other glass processing issue (such as sulfate solubility or crystal formation affecting durability). For example, consider an extreme case in which only one frit out of the 1755 being used in this study is identified for a particular sludge option that yields a reasonable operating window. Although that option may not be ruled out from a feasibility perspective, there is no opportunity to adjust the frit composition to influence melt rate. The performance of the system in DWPF would be defined based on the use of that one frit without the possibility to make any necessary adjustments. On the other side of this hypothetical discussion, consider a sludge option in which multiple frits are available that yield relatively large operating windows. In this scenario, frit development efforts can evaluate melt rate over the compositional region covered by the candidate frits and make frit recommendation decisions based on experimental melt rate data and other required inputs. Flexibility during the frit recommendation process has been and should continue to be a valuable asset when trying to meet DWPF processing or contractual expectations.

For the MAR evaluation, WLs from 25 through 50\% (in increments of 1\%) were explored, leading to 26 glass compositions for each of the 26 sludges and frit (1755 in number) combination considered. Thus, 1,186,380 glass compositions were evaluated against the PCCS MAR criteria as the first step in the paper study. For each glass, the property predictions assessed included those for liquidus temperature $\left(T_{L}\right)$, viscosity $(\eta)$, durability (normalized leachate for boron, $\mathrm{NL}[\mathrm{B}]$ ), $\mathrm{Al}_{2} \mathrm{O}_{3}$ and/or sum of alkali and their associated constraints ${ }^{\mathrm{b}}$, high viscosity (highv), low viscosity (lowv), high chromia concentration $\left(\mathrm{Cr}_{2} \mathrm{O}_{3}\right)$, high sulfate concentration $\left(\mathrm{SO}_{4}{ }^{2-}\right)^{\mathrm{c}}$ and nepheline formation. The MAR assessments were based on the current version of PCCS as described by Brown et al. (2006) [6].

\subsection{MAR Assessment Results - Paper Study}

With 26 different sludge compositions and so many different frits, summarizing the outcomes of the paper study in a manner that balances detail with insight is a challenge. One option is presented in Table 3-1, which provides the widths of the projected operating windows (in WL) and the number of potential frits providing a window of each width for each of the sludge projections. Note that the entries in the row for each of the sludges do not necessarily sum to 1755 , since for some of the sludges, none of the frits provided any type of operating window whatsoever.

\footnotetext{
${ }^{b}$ For sludge-only processing, the $\mathrm{Al}_{2} \mathrm{O}_{3}$ and sum of alkali constraints can be used to replace the homogeneity constraint and its auxiliary constraints (low frit, high frit) (Herman et al. (2002)). Although DWPF is currently operating a sludge-only flowsheet, the algorithms in PCCS still contain homogeneity (at the PAR) and the auxiliary constraints. Although there is a high probability that the $\mathrm{Al}_{2} \mathrm{O}_{3}$ and sum of alkali could also replace homogeneity and the auxiliary constraints for coupled operations, this report utilized the exact algorithms currently imposed in PCCS to assess the projected operating windows. It should be noted that this does create a potentially conservative evaluation on the projected operating windows for those systems found to be homogeneity limited at lower WLs or where predicted issues associated with its auxiliary constraints occur at other WLs of interest. The application of the current PCCS system will not have an impact on the results or conclusions from this study.

C It should be noted the current MAR assessment utilized a $\mathrm{SO}_{4}{ }^{2-}$ MAR constraint of $0.4 \mathrm{wt} \%$ in glass which would have limited or restricted some operating windows if not overridden. The technical basis to override the $0.4 \mathrm{wt} \%$ limit relies on the applicability of the $0.6 \mathrm{wt} \%$ limit utilized for SB3 and SB4 to future sludge batches. That is, it was assumed that the $0.6 \mathrm{wt} \% \mathrm{SO}_{4}{ }^{2-}$ limit would be applicable to all future sludge batches.
} 
To aid in interpreting this table, consider the entry of 1 (cell shaded green) for WALD-SB6 for an operating window width of 11 . This indicates that only 1 of the 1755 candidate frits provides an operating window with a width of exactly 11 points (possibly from 25 to $35 \% \mathrm{WL}$ ). This is the widest operating interval for SB6 (WALD). The result suggests that the projected operating window for SB6 (with Al-dissolution) is: (1) relatively small (in fact the smallest window evaluated in this study) and (2) at the maximum operating window only one frit is available so melt rate adjustments through compositional changes to the frit are not available. There are no frits available that provide operating windows 12 points (or higher) in width for WALD-SB6. Sludge Batch 6 without Al-dissolution (WOALD-SB6) has a slightly larger window (13 points wide) but still appears to be problematic (only 4 frits available even with this small operating window). These results indicate that SB6 (with or without Al-dissolution) would, at best, require a different frit grid to obtain a reasonable projected operating window based on the current PCCS models and constraints. Alternatively, different blending and/or washing strategies should be considered for SB6 if higher WLs are required to meet processing expectations or contractual requirements. 
Table 3-1. Number of Frits Out of the Candidate Set of 1755 that Provide a

Projected Operating Window in WL of the Indicated Widthd.

\begin{tabular}{|c|c|c|c|c|c|c|c|c|c|c|c|c|c|c|c|c|c|c|c|c|c|c|c|}
\hline \multirow{2}{*}{$\begin{array}{l}\text { Sludge } \\
\text { Type }\end{array}$} & \multicolumn{23}{|c|}{ Projected Operating Window Width (in points of WL) in the WL Interval from $25 \%$ to $50 \%$} \\
\hline & 1 & 2 & 3 & 4 & 5 & 6 & 7 & 8 & 9 & 10 & 11 & 12 & 13 & 14 & 15 & 16 & 17 & 18 & 19 & 20 & 21 & 22 & 23 \\
\hline WALD - SB6 & 64 & 101 & 107 & 82 & 103 & 102 & 90 & 65 & 44 & 14 & 1 & & & & & & & & & & & & \\
\hline WALD - SB7 & 24 & 33 & 42 & 50 & 46 & 52 & 53 & 66 & 54 & 80 & 81 & 65 & 92 & 73 & 47 & 55 & 34 & 19 & 9 & & & & \\
\hline WALD - SB8 & 47 & 40 & 51 & 50 & 56 & 66 & 76 & 76 & 82 & 63 & 93 & 61 & 41 & 45 & 24 & 13 & 1 & & & & & & \\
\hline WALD - SB9 & 35 & 37 & 43 & 42 & 49 & 55 & 47 & 41 & 48 & 49 & 77 & 57 & 60 & 77 & 57 & 58 & 49 & 32 & 28 & 8 & 3 & & \\
\hline WALD - SB10 & 46 & 43 & 46 & 50 & 42 & 48 & 48 & 67 & 56 & 164 & 50 & 80 & 43 & 61 & 46 & 20 & 21 & 7 & & & & & \\
\hline WALD - SB11 & 44 & 46 & 47 & 48 & 42 & 47 & 48 & 53 & 49 & 75 & 66 & 80 & 73 & 69 & 78 & 67 & 22 & 35 & 12 & 3 & 1 & & \\
\hline WALD - SB12 & 24 & 42 & 39 & 49 & 43 & 33 & 40 & 39 & 50 & 48 & 51 & 60 & 64 & 75 & 85 & 65 & 72 & 73 & 44 & 44 & 16 & 10 & \\
\hline WALD - SB13 & 31 & 47 & 46 & 39 & 33 & 36 & 50 & 44 & 60 & 56 & 63 & 83 & 61 & 95 & 90 & 43 & 59 & 50 & 24 & 8 & 4 & & \\
\hline WALD - SB14 & 28 & 38 & 44 & 51 & 48 & 59 & 67 & 61 & 92 & 69 & 77 & 99 & 67 & 45 & 47 & 31 & 11 & 2 & & & & & \\
\hline WALD - SB15 & 48 & 59 & 59 & 57 & 86 & 75 & 105 & 65 & 58 & 78 & 38 & 19 & 17 & 7 & & & & & & & & & \\
\hline WALD - SB16 & 46 & 38 & 50 & 46 & 50 & 54 & 55 & 53 & 82 & 70 & 94 & 55 & 76 & 60 & 35 & 21 & 19 & 4 & & & & & \\
\hline WALD - SB17 & 42 & 43 & 42 & 44 & 47 & 56 & 42 & 80 & 68 & 75 & 59 & 76 & 87 & 34 & 66 & 31 & 16 & 13 & 3 & & & & \\
\hline WOALD - SB6 & 27 & 35 & 64 & 51 & 85 & 96 & 133 & 130 & 103 & 81 & 61 & 27 & 4 & & & & & & & & & & \\
\hline WOALD - SB7 & 20 & 37 & 22 & 30 & 38 & 20 & 43 & 26 & 35 & 53 & 49 & 55 & 97 & 109 & 92 & 94 & 95 & 64 & 30 & 7 & & & \\
\hline WOALD - SB8 & 41 & 13 & 40 & 19 & 40 & 39 & 18 & 47 & 36 & 26 & 56 & 49 & 65 & 74 & 87 & 116 & 98 & 63 & 71 & 41 & 11 & & \\
\hline WOALD - SB9 & 35 & 27 & 30 & 43 & 14 & 43 & 36 & 23 & 48 & 47 & 29 & 48 & 75 & 75 & 96 & 103 & 84 & 82 & 66 & 35 & 16 & 3 & \\
\hline WOALD - SB10 & 35 & 33 & 23 & 43 & 17 & 41 & 43 & 19 & 44 & 43 & 40 & 42 & 77 & 68 & 104 & 99 & 89 & 85 & 67 & 27 & 17 & 3 & \\
\hline WOALD - SB11 & 22 & 36 & 19 & 43 & 12 & 45 & 27 & 32 & 47 & 24 & 43 & 61 & 58 & 80 & 95 & 109 & 112 & 72 & 55 & 34 & 17 & 1 & \\
\hline WOALD - SB12 & 42 & 13 & 41 & 29 & 29 & 45 & 23 & 36 & 49 & 41 & 29 & 53 & 59 & 79 & 93 & 89 & 101 & 84 & 54 & 49 & 24 & 2 & \\
\hline WOALD - SB13 & 38 & 19 & 46 & 42 & 35 & 33 & 53 & 69 & 73 & 89 & 96 & 105 & 94 & 90 & 56 & 32 & 9 & & & & & & \\
\hline WOALD - SB14 & 48 & 58 & 69 & 75 & 89 & 86 & 101 & 98 & 95 & 75 & 54 & 24 & 4 & & & & & & & & & & \\
\hline WOALD - SB15 & 42 & 41 & 17 & 44 & 40 & 21 & 42 & 52 & 50 & 39 & 72 & 81 & 91 & 111 & 106 & 71 & 56 & 43 & 11 & & & & \\
\hline WOALD - SB16 & 22 & 44 & 15 & 39 & 39 & 22 & 49 & 34 & 25 & 51 & 50 & 49 & 60 & 86 & 90 & 96 & 106 & 78 & 57 & 40 & 19 & 1 & \\
\hline WOALD - SB17 & 14 & 44 & 15 & 39 & 21 & 30 & 28 & 40 & 36 & 52 & 48 & 76 & 65 & 77 & 78 & 68 & 84 & 77 & 67 & 65 & 29 & 14 & 1 \\
\hline WOALD - SB18 & 22 & 40 & 36 & 50 & 54 & 68 & 80 & 83 & 84 & 86 & 80 & 76 & 74 & 72 & 64 & 43 & 25 & 6 & 1 & & & & \\
\hline WOALD - SB19 & 28 & 48 & 53 & 65 & 94 & 75 & 92 & 85 & 89 & 81 & 77 & 76 & 59 & 46 & 14 & 1 & & & & & & & \\
\hline
\end{tabular}

$\mathrm{d}$ The green shading for WALD-SB6 highlights the number of frits available at the widest operating window for that sludge projection. The yellow shading indicates the number of frits available for the proposed reasonable operating width of 17 points. 
Next, consider the SB7 with Al-dissolution (WALD-SB7) system. The maximum projected operating window is 19 points wide (possibly $25-43 \% \mathrm{WL}$ ) with nine frits available to adjust for melt rate. Considering a 17 point wide window as reasonable (yellow shaded column in Table 3-1), the WALD-SB7 system has 34 frits capable of providing this window size, which provides even more compositional flexibility for melt rate adjustments. The SB7 without Al-dissolution (WOALD-SB7) has a maximum operating window width of 20 points (possibly $25-44 \% \mathrm{WL}$ ) with seven candidate frits. Using the 17 point width criteria as reasonable, 95 frits are available. This provides more compositional flexibility to adjust melt rate (relative to the with Aldissolution SB7 flowsheet), although both are reasonably sound from a MAR based assessment perspective and have a relatively large number of frits to select from. One of the critical inputs on the question of whether to implement the Al-dissolution process for SB7 would be the melt rate differences between the two flowsheets and what the maximum waste throughput curves were for each system. That is, could one of the 95 frits available for the without Al-dissolution flowsheet yield a relatively high melt rate and have the potential to increase waste throughput enough to off-set the lower mass associated with the "with Al-dissolution" flowsheet for SB7? This concept is further explored in Section 4.0.

Some general observations from Table 3-1 include:

(1) With the exception of $\sim 6$ flowsheets (see (2) below), most of the sludge options (both with and without Al-dissolution) combined with the array of frits provide relatively wide operating windows.

(2) The most challenging or problematic sludge options include:

a. SB6 - with and without Al-dissolution: both flowsheets have very limited operating windows (11 and 13 points wide) for the frits used in this evaluation.

b. SB8 with Al-dissolution: although a projected operating window of a 17 point width exists, only 1 of the 1755 frits is available, and this limits the compositional flexibility required to adjust melt rate or some other performance constraint.

c. SB15 with Al-dissolution: largest operating window width is only 14 points wide with 7 of the 1755 frits being candidates.

d. SB14 without Al-dissolution: largest operating window width is only 13 points wide with only 4 candidate frits.

e. SB19 without Al-dissolution: largest operating window width is 16 points wide with only 1 candidate frit.

(3) In general, using the 17 point width as a guide for a reasonable operating window indicates that the "without Al-dissolution" flowsheets appear to provide more compositional flexibility in frit selection.

Based on the general observations of the paper study assessments with the projected operating windows (and excluding the "problematic" sludge options discussed above), there is essentially no clear distinction between the two flowsheets to drive an Al-dissolution implementation decision. That is, comparable operating windows can be achieved through the frit development and selection process, even though a difference in the number of available frits exists. One could interpret this general summary statement to suggest that given frit development efforts can compensate for the different pretreatment strategies by yielding equivalent operating windows or maximum WL targets, and the lower sludge mass as a result of Al-dissolution would obviously result in minimizing the number of cans produced at DWPF. Although the authors agree that the basic mathematics to support this stance are technically sound, one needs to ask a series of additional questions: Is a reduction in the sludge mass going to DWPF (which should translate into a lower canister production count) the only parameter of interest? What about facility 
operating times (or mission life) for both tank farm and DWPF operations? Section 4.0 provides an overview of historical melt rate versus waste loading trends observed in DWPF for both high and low Al-based sludges. Based on those trends, waste throughput concepts are presented that provide possible impacts with respect to facility operating times and/or mission life.

\subsection{Melt Rate Versus Waste Loading: A Historical Review}

Tthe maximum waste throughput at DWPF (amount of sludge processed per unit time) is a function of waste loading and melt rate. The historical general trend between melt rate and WL indicates that as WL increases, melt rate gradually decreases - see Figure 4-1. This trend leads to a situation in which the maximum waste throughput is not found at the maximum WL allowed by PCCS but at some intermediate WL determined experimentally or during DWPF operations again refer to Figure 4-1 for a conceptual view of these trends. Therefore, if one were solely interested in minimizing the number of canisters produced, DWPF should target the maximum WL allowed by PCCS model predictions. This would yield a minimum canister count. But based on previous operational metrics, this strategy could lead to a significant increase in canister pour times (or production rates), which ultimately could increase the overall mission life of both the tank farm and DWPF.

Assuming mission life is a critical aspect or input into the Al-dissolution implementation decision, sole use of the MAR assessment results and the general comments about "comparable" operating windows with and without Al-dissolution could lead one to make a sub-optimal decision. More specifically, the MAR assessments provide no insight into melt rate and/or waste throughput. Consider the two scenarios shown in Figure 4-2 and Figure 4-3 in which mission life is dependent upon the quantity of waste vitrified and waste throughput, which is a function of the melt rate versus waste loading curve. In Figure 4-2, the blue line represents a nominal waste throughput (lb/hr) for the without Al-dissolution flowsheet. The red line represents the with Al-dissolution flowsheet waste throughput. The difference in the amount of waste to be immobilized is strictly a function of the efficiency of the Al-dissolution process and the sludge batches to which it is applied. In this example, the waste throughput for the without Al-dissolution flowsheet is higher than the with Al-dissolution flowsheet (based on the slope) but not high enough to overcome the increased mass. Therefore, one could conclude that Al-dissolution would ultimately reduce overall mission life even though it has a lower waste throughput.

Alternatively, consider the case in which the waste throughput for the without Al-dissolution flowsheet is substantially higher (Figure 4-3). Under this scenario, it could be possible that the higher waste throughput would overcome the mass differences between the two flowsheets resulting in a shorter mission life. Could this be the case given the MAR assessments (in general) provide more flexibility for frit development efforts to improve melt rate based strictly on the number of frits available to provide comparable operating windows? This question is a primary focus of the experimental melt rate portion of this program which will be documented in a subsequent report. 


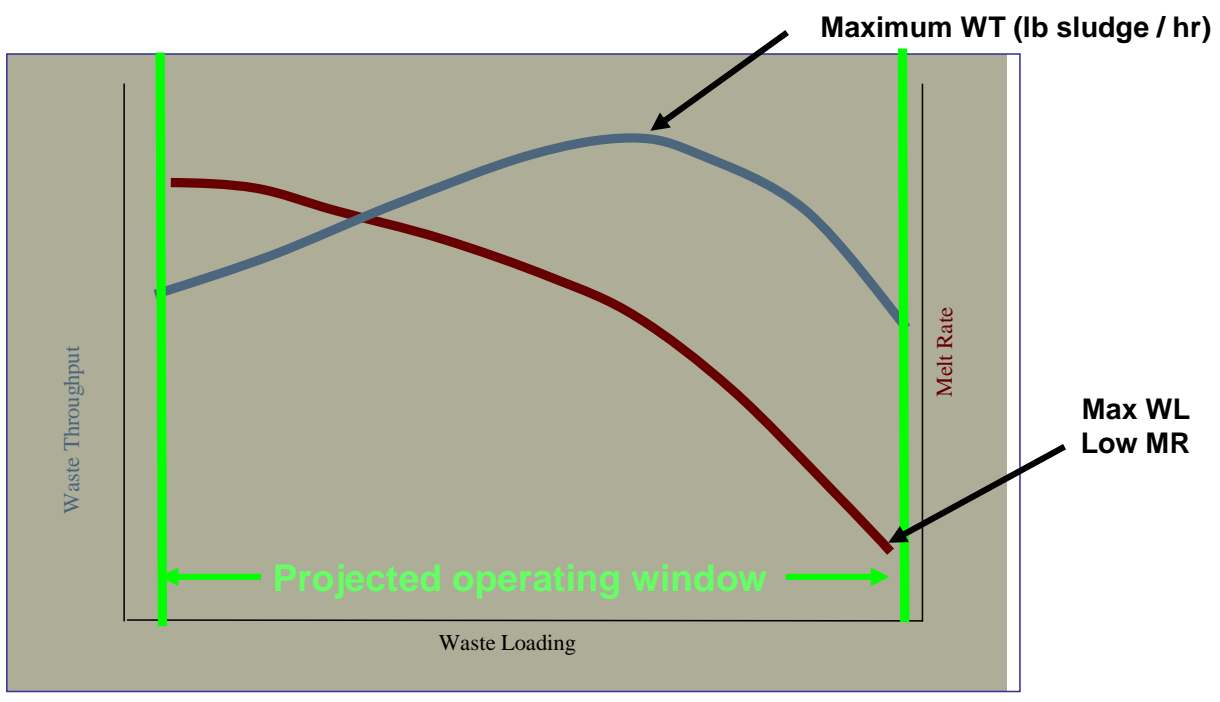

Figure 4-1. Historical Trend Between Melt Rate and Waste Loading.

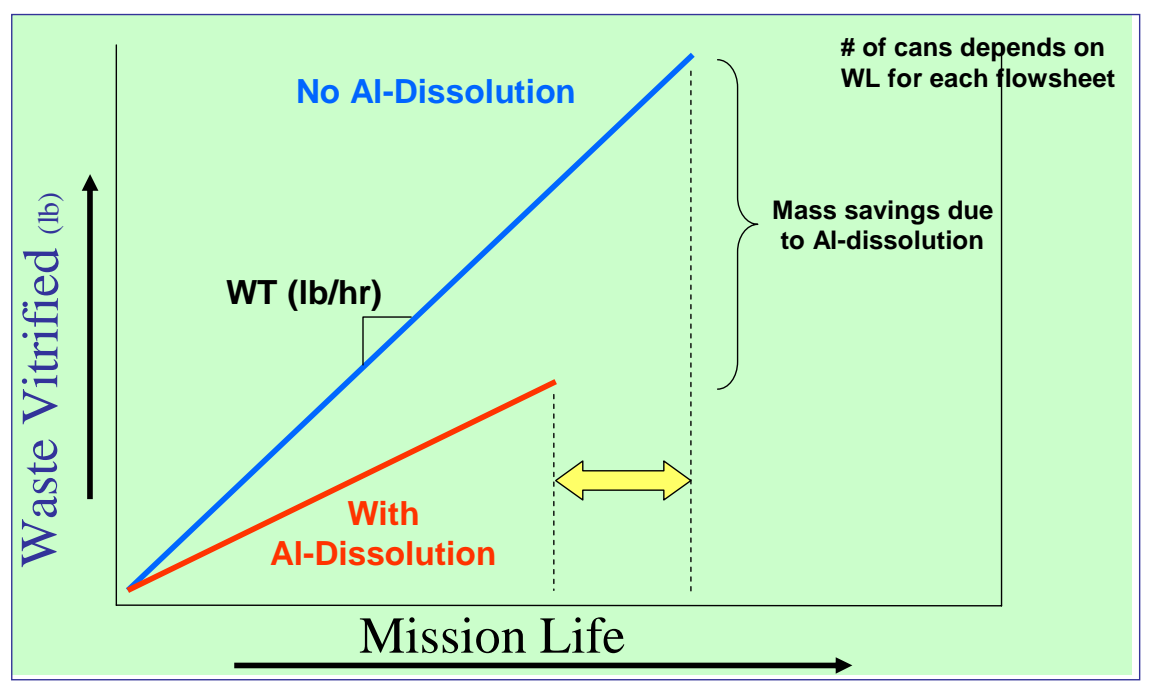

Figure 4-2. Schematic in which Higher WT for "Without Al-Dissolution" Does Not Overcome Mass Reduction in Terms of Mission Life. 


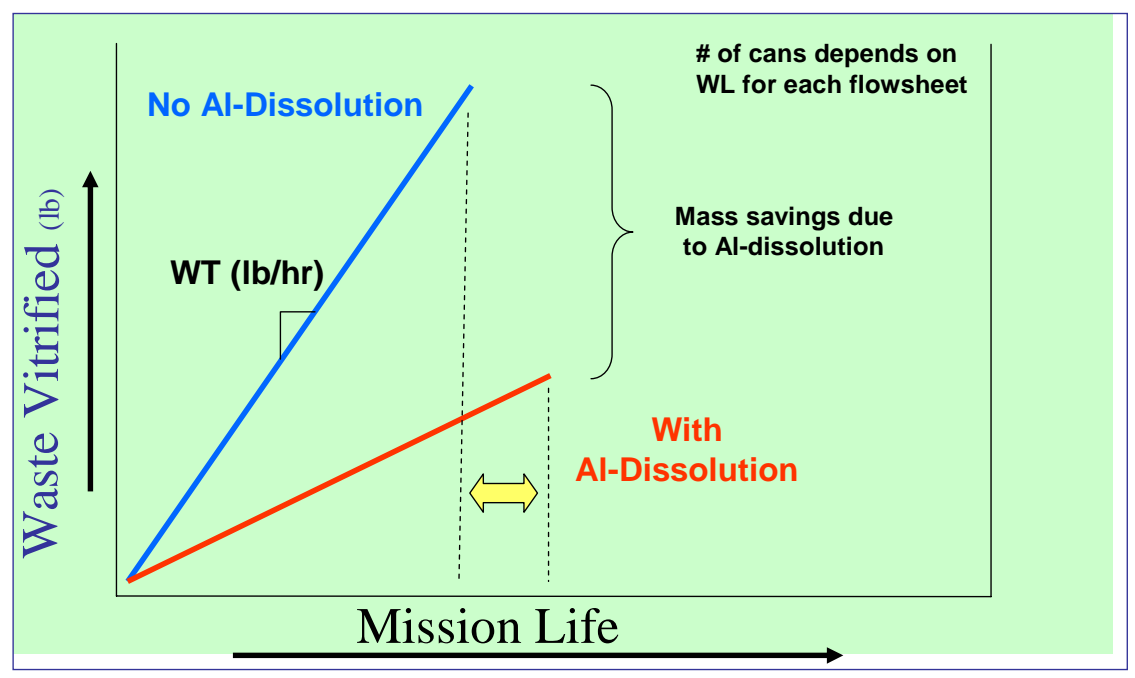

Figure 4-3. Schematic in which Higher WT for "Without Al-Dissolution" Does Overcome Mass Reduction in Terms of Mission Life.

Recent DWPF processing could provide some insight into the potential throughput trends for high and low Al-based sludges. For example, consider DWPF operations for SB3 (Purex based feed, low $\mathrm{Al}_{2} \mathrm{O}_{3}$ and high $\mathrm{Na}_{2} \mathrm{O}$ ) and $\mathrm{SB} 4\left(\mathrm{HM}\right.$ based feed, high $\mathrm{Al}_{2} \mathrm{O}_{3}$ ). Frit 418 was used as the primary frit to process SB3, which ultimately yielded a maximum waste throughput value of $\sim 55$ $\mathrm{lb} / \mathrm{hr}$ when targeting 38\% WL. Note the projected operating window for the Frit 418 - SB3 system was $~ 25$ - 45\% WL, but lower melt rates were experienced at WLs of 38\% and greater. Frit development for SB3 (leading to the Frit 418 recommendation) was primarily based on increasing the $\mathrm{Na}_{2} \mathrm{O}$ content of the frit to reduce liquidus temperature predictions and improve melt rate. Other frit components, $\mathrm{B}_{2} \mathrm{O}_{3}$ and $\mathrm{Li}_{2} \mathrm{O}$, did not have a significant impact on melt rate for that system.

Current processing of SB4 (HM based feed) is utilizing Frit 510 which is a high $\mathrm{B}_{2} \mathrm{O}_{3}$ based frit (14 wt\% relative to $8 \mathrm{wt} \%$ in Frit 418). Higher $\mathrm{B}_{2} \mathrm{O}_{3}$ concentrations were found during frit development efforts [9] to improve melt rate - with $\mathrm{Na}_{2} \mathrm{O}$ having less influence on melt rate than observed in the Frit 418 development for SB3. Although the current targeted WL is only 34\%, and the wt\% solids in the feed is relatively low due to pump in-leakage, waste throughputs are approximately $60-65 \mathrm{lb} / \mathrm{hr}$ with the CPC operations limiting production. With indications that higher feed rates and/or higher WLs could be targeted, even greater waste throughputs could be achieved for this relatively high $\mathrm{Al}_{2} \mathrm{O}_{3}$ feed. Not knowing what WL will yield the maximum waste throughput for this system, the question one should ask is: Could the higher throughputs for this system overcome the same sludge (SB4) having undergone Al-dissolution, which may ultimately result in a sludge batch similar to SB3 (higher $\mathrm{Fe}_{2} \mathrm{O}_{3}$, lower $\mathrm{Al}_{2} \mathrm{O}_{3}$ )? More specifically, assume the maximum waste throughput for the Frit 510 - SB4 system was determined to be on the order of $80 \mathrm{lb} / \mathrm{hr}$. If LWO had implemented Al-dissolution for SB4 (reducing the overall mass to be immobilized) but maximum waste throughput was similar to that observed for SB3 ( $55 \mathrm{lb} / \mathrm{hr}$ ), which flowsheet would be completed first by DWPF (i.e., which flowsheet would have the minimum mission life impact)? Even if the "without Al-dissolution" flowsheet did not fully reduce the overall mission life, are there other factors (e.g., implementation cost of Aldissolution or rheology impacts) that would play a role in the decision making process? 
Although experimentally determining the waste loading versus melt rate trends for each of the 26 sludge batches provided by LWO would be of great value, time and budget constraints ultimately place restrictions on that possibility. Therefore, developing a defensible strategy that could be used to provide general insights into the advantages or impacts of Al-dissolution to overall mission life is paramount for this task. That is, how does one select a "worst case" scenario for each flowsheet with respect to melt rate or waste throughput? Even if successful on that issue, how does one select the optimal frit to use in that melt rate assessment to provide each flowsheet with the best probability/possibility to show its optimal behavior?

\subsection{Development of Sludge Clusters}

The approach taken was to investigate possible groupings of the projected sludge batches based upon commonalities in their compositions using the Cluster Analysis routines of JMP [10]. That is, can the 26 sludges be grouped according to commonalities of the major sludge components? Table 5-1 provides those oxides that were used as inputs into the grouping routine in JMP.

Table 5-1. Components Used to Cluster Sludge Compositions.

\begin{tabular}{||c||}
\hline Sludge $\mathrm{Al}_{2} \mathrm{O}_{3}$ \\
\hline Sludge $\mathrm{Fe}_{2} \mathrm{O}_{3}$ \\
\hline Sludge $\mathrm{Na}_{2} \mathrm{O}$ \\
\hline Sludge $\mathrm{MnO}$ \\
\hline Sludge $\mathrm{CaO}$ \\
\hline Sludge $\mathrm{NiO}$ \\
\hline Sludge $\mathrm{TiO}_{2}$ \\
\hline
\end{tabular}

Figure 5-1 provides a schematic indicating the results of JMP's Cluster Analysis routine. The first groupings isolated the pair (WOALD-SB6 and WALD-SB6) from the other sludge projections. This was reassuring given the behavior of these two sludge compositions relative to the MAR results of Table 3-1. JMP then separated WOALD-SB18 and WOALD-SB19 from the remaining sludges based on compositional likeness. Subsequent JMP requests isolated WALDSB7 through WALD-SB16, which formed their own cluster, and this isolated WOALD-SB17 from the remaining sludges to form an additional cluster. This resulted in the five groupings shown in Figure 5-1 with the different colors and symbols being used to represent the clusters. Exhibit A2 in the Appendix provides scatter plots of these sludge compositions color-coded as in Figure 5-1 for the seven oxides of Table 5-1. 
WSRC-STI-2007-00688

Revision 0

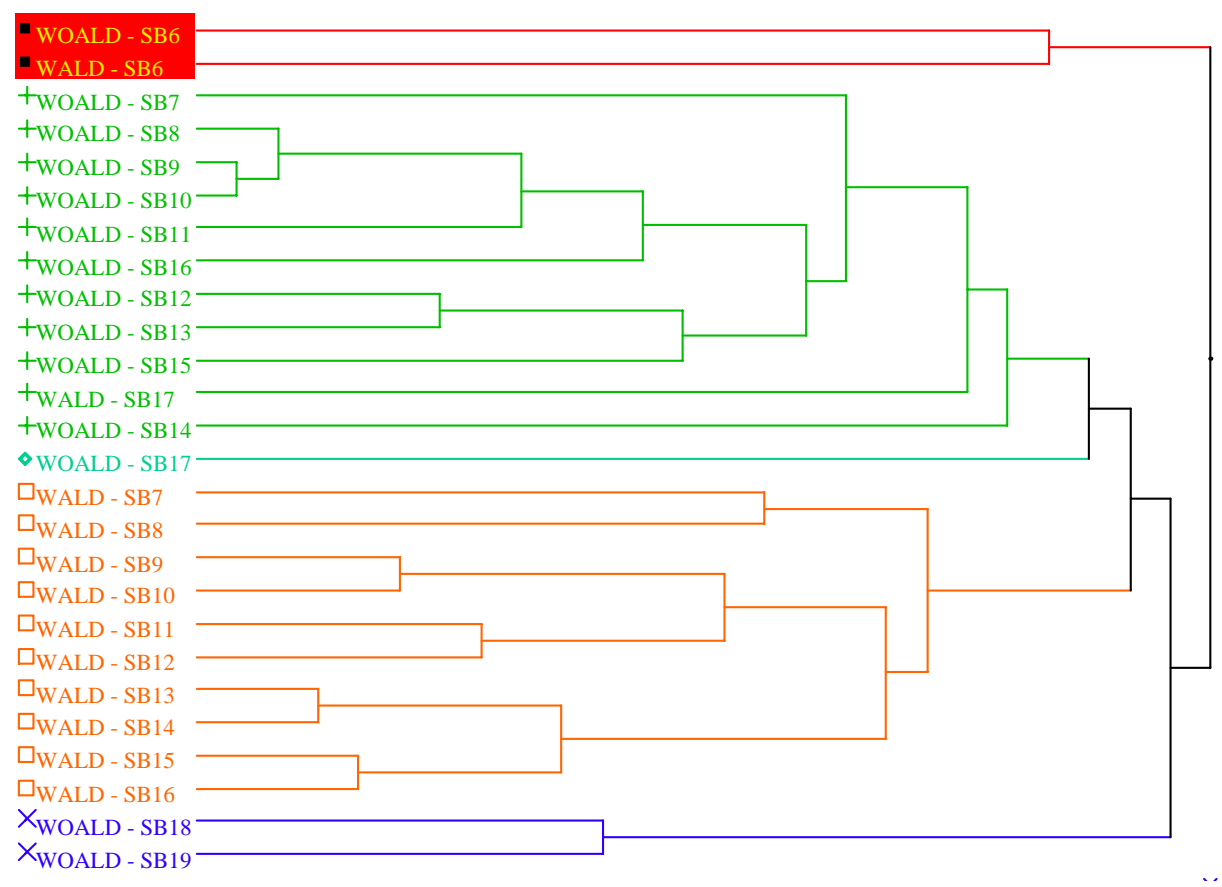

Figure 5-1. Schematic of Clusters Identified Using JMP

The two clusters containing the largest number of projected sludge batches were labeled as Cluster 2 (consisting of WOALD-SB7, WOALD-SB7, WOALD-SB9, WOALD-SB10, WOALD-SB11, WOALD-SB12, WOALD-SB13, WOALD-SB14, WOALD-SB15, WOALDSB16, and WALD-SB17) and Cluster 4 (consisting of WALD-7, WALD-8, WALD-9, WALD-10, WALD-11, WALD-12, WALD-13, WALD-14, WALD-15, and WALD-16). With the exception of WALD-SB17 in Cluster 2, the two clusters essentially represent, not surprisingly, the with and without Al-dissolution flowsheets. The average composition was computed for each of these clusters and is presented in Table 5-2. It should be noted that the average composition for each cluster was strictly a mathematical average (as opposed to a weighed average based on mass for example). Again, Cluster 4 essentially represents an average sludge composition based on the implementation of high temperature Al-dissolution. Cluster 2 represents an average sludge composition without Al-dissolution. Identification of these two sludges provides a logistical solution to the problem of the large number of sludges, while still providing an opportunity to gain general insights into the impacts of Al-dissolution on the projected operating windows as well as melt rate and/or waste throughput assessments. 
WSRC-STI-2007-00688

Revision 0

Table 5-2. Average Composition of Cluster 2 and Cluster 4.

\begin{tabular}{||c|c|c||}
\hline Oxide & $\begin{array}{c}\text { Cluster 2 } \\
\text { average }\end{array}$ & $\begin{array}{c}\text { Cluster 4 } \\
\text { average }\end{array}$ \\
\hline $\mathrm{Al}_{2} \mathrm{O}_{3}$ & 23.10 & 14.62 \\
\hline $\mathrm{BaO}$ & 0.21 & 0.25 \\
\hline $\mathrm{CaO}$ & 2.63 & 3.26 \\
\hline $\mathrm{Ce}_{2} \mathrm{O}_{3}$ & 0.55 & 0.58 \\
\hline $\mathrm{Cr}_{2} \mathrm{O}_{3}$ & 0.27 & 0.34 \\
\hline $\mathrm{CuO}$ & 0.08 & 0.11 \\
\hline $\mathrm{Fe}_{2} \mathrm{O}_{3}$ & 30.81 & 35.17 \\
\hline $\mathrm{K}_{2} \mathrm{O}$ & 0.18 & 0.23 \\
\hline $\mathrm{La}_{2} \mathrm{O}_{3}$ & 0.20 & 0.22 \\
\hline $\mathrm{MgO}_{\mathrm{OgO}}$ & 0.41 & 0.47 \\
\hline $\mathrm{MnO}$ & 4.00 & 5.17 \\
\hline $\mathrm{Na}_{2} \mathrm{O}$ & 20.25 & 21.21 \\
\hline $\mathrm{NiO} \mathrm{PbO}$ & 1.16 & 1.28 \\
\hline $\mathrm{SO}_{4}$ & 0.24 & 0.25 \\
\hline $\mathrm{SiO}_{2}$ & 3.35 & 5.09 \\
\hline $\mathrm{ThO}_{2}$ & 1.00 & 1.20 \\
\hline $\mathrm{TiO}_{2}$ & 3.29 & 2.77 \\
\hline $\mathrm{U}_{3} \mathrm{O}_{8}$ & 7.44 & 6.76 \\
\hline $\mathrm{ZnO}$ & 0.13 & 0.16 \\
\hline $\mathrm{ZrO}_{2}$ & 0.50 & 0.61 \\
\hline \hline
\end{tabular}

To evaluate the projected operating windows, these two sludge compositions were evaluated against the MAR criteria using the 1755 candidate frits for WLs from 25 to 50\%. Table 5-3 provides a summary of the outcomes from this MAR evaluation in a form similar to that of Table $3-1$; that is, the number of frits out of the 1755 that provided an operating window of the indicated width. For example, using the 17 point width as a reasonable window, Cluster 2 (without Al-dissolution) has 78 frits available. For Cluster 4 (with Al-dissolution), 42 frits are available to produce this same window width.

The outcome of this MAR assessment mirrors the MAR results of the sludge compositions without and with $\mathrm{Al}$ dissolution in general. Both systems show attractive projected operating windows. There may be more frits that provide such projections without Al dissolution than with, but there is no indication of an inability to find, for each of these two sludge compositions (Cluster 2 and Cluster 4 averages), a frit that will provide an attractive projected operating window. Thus, if mission life is a critical aspect of the decision making process, experimental assessments of the melt rate versus waste loading trends are warranted. 
WSRC-STI-2007-00688

Revision 0

Table 5-3. Number of Frits that Provide Projecting Operating Windows of the Indicated Width for Cluster 2 and Cluster 4

\begin{tabular}{||c|c|c||}
\hline $\begin{array}{c}\text { Operating } \\
\text { Window } \\
\text { Width }\end{array}$ & $\begin{array}{c}\text { Cluster 2 } \\
\text { average }\end{array}$ & $\begin{array}{c}\text { Cluster 4 } \\
\text { average }\end{array}$ \\
\hline 1 & 42 & 35 \\
\hline 2 & 22 & 50 \\
\hline 3 & 33 & 41 \\
\hline 4 & 43 & 49 \\
\hline 5 & 18 & 40 \\
\hline 6 & 39 & 51 \\
\hline 7 & 47 & 47 \\
\hline 8 & 25 & 50 \\
\hline 9 & 35 & 61 \\
\hline 10 & 49 & 53 \\
\hline 11 & 53 & 78 \\
\hline 12 & 42 & 87 \\
\hline 13 & 63 & 64 \\
\hline 14 & 65 & 78 \\
\hline 15 & 89 & 61 \\
\hline 16 & 116 & 52 \\
\hline 17 & 78 & 42 \\
\hline 18 & 81 & 28 \\
\hline 19 & 69 & 7 \\
\hline 20 & 38 & 6 \\
\hline 21 & 12 & 1 \\
\hline
\end{tabular}

\subsection{Selection of Candidate Frit Compositions for Melt Rate Testing}

With the MAR assessments complete for the Cluster 2 and Cluster 4, the issue now becomes one of selecting frits to use to explore the melt rate for the glass systems representing sludges without $\mathrm{Al}$ dissolution versus glass systems representing sludges with Al dissolution. Since there are no models that relate melt rate to glass composition to provide insight into this question for candidate frits of interest, any melt rate comparisons must be conducted experimentally. As previously mentioned, the compositional trends to influence melt rate for a given sludge have historically been centered on either increasing the $\mathrm{Na}_{2} \mathrm{O}$ content (for $\mathrm{SB} 3$, low $\mathrm{Al}_{2} \mathrm{O}_{3}$, high $\mathrm{Fe}_{2} \mathrm{O}_{3}$ ) or increasing the boron and/or sodium content (for SB4, high $\mathrm{Al}_{2} \mathrm{O}_{3}$, low $\mathrm{Fe}_{2} \mathrm{O}_{3}$ ). Thus, one additional use of the MAR assessment is in the identification of frits that provide a range of possible levels of these two critical frit components while leading to reasonable projected operating windows.

Figure 6-1 and Figure 6-2 present plots for the Cluster 2 average composition and the Cluster \#4 average composition, respectively, that indicate the $\mathrm{Na}_{2} \mathrm{O}$ and $\mathrm{B}_{2} \mathrm{O}_{3}$ content of various frits that yield projected operating window widths (as plotted on the y-axis). It should be noted that the $\mathrm{Li}_{2} \mathrm{O}$ content for the frits was fixed at $8 \mathrm{wt} \%$. This was based on the fact that both Frit 418 and Frit 510 contain $8 \mathrm{wt} \% \mathrm{Li}_{2} \mathrm{O}$. These two frits processed well in DWPF with SB3 and SB4, 
respectively. To aid in the interpretation of these results, consider the green diamond located at 8 wt $\% \mathrm{~B}_{2} \mathrm{O}_{3}$ and $11 \mathrm{wt} \% \mathrm{Na}_{2} \mathrm{O}$ in Figure 6-1. This frit $\left(8 \% \mathrm{~B}_{2} \mathrm{O}_{3}, 11 \% \mathrm{Na}_{2} \mathrm{O}, 8 \% \mathrm{Li}_{2} \mathrm{O}\right.$, and $73 \%$ $\mathrm{SiO}_{2}$ ), when coupled with Cluster 2 (without Al-dissolution), provides a 19 point wide operating window, as indicated by the green diamond symbol. The compositional region covered by the frits that provide operating window widths of 15 points (red squares) and greater (maximum 22 as indicated by the orange " $\mathrm{z}$ "s) ranges from $8-17 \mathrm{wt} \% \mathrm{~B}_{2} \mathrm{O}_{3}$ and $4-11$ wt $\% \mathrm{Na}_{2} \mathrm{O}$. With respect to melt rate assessments, the critical question becomes: which frit or series of frits should be selected to experimentally assess the melt rate versus waste loading trend for Cluster 2 (without Al-Dissolution)? Based on historical trends (SB4 - high $\mathrm{Al}_{2} \mathrm{O}_{3}$ feed), the primary driver is $\mathrm{B}_{2} \mathrm{O}_{3}$ content - with higher concentrations potentially leading to higher melt rates at a fixed waste loading. That being said, one candidate would be the $17 \mathrm{wt} \% \mathrm{~B}_{2} \mathrm{O}_{3}$ frit located at the bottom right corner in Figure 6-1. This frit $\left(17 \% \mathrm{~B}_{2} \mathrm{O}_{3}, 5 \% \mathrm{Na}_{2} \mathrm{O}, 8 \% \mathrm{Li}_{2} \mathrm{O}\right.$ and $\left.70 \% \mathrm{SiO}_{2}\right)$, which yields an 18 point wide operating window, is a primary frit of interest. Again, using the historical trends in melt rate as a guide to the frit selection process, one could consider the frits lying along the maximum $\mathrm{B}_{2} \mathrm{O}_{3}-\mathrm{Na}_{2} \mathrm{O}$ line, shown in Figure 6-1, as leading candidates. Using this as a basis, three additional frits were selected to carry forward in the experimental assessments of melt rate for Cluster 2. These four frits are highlighted (circled) in Figure 6-1. Although these four frits provide projected operating windows that are at least 18 points wide, there are other frits that yield widths of 22 points for Cluster 2 (denoted by the "z"'s). The symbols are indicative of the operating window width, as indicated in the legend of Figure 6-1 and Figure 6-2. Selecting one of these three frits would provide the opportunity to assess the melt rate versus WL curve at higher WLs, which could translate into higher waste throughputs. Therefore, the frit composition with $9 \% \mathrm{~B}_{2} \mathrm{O}_{3}$ and $8 \% \mathrm{Na}_{2} \mathrm{O}$ was selected as a fifth primary candidate. Table $6-1$ summarizes the five candidate frits that will be carried forward in an experimental assessment of melt rate for Cluster 2.

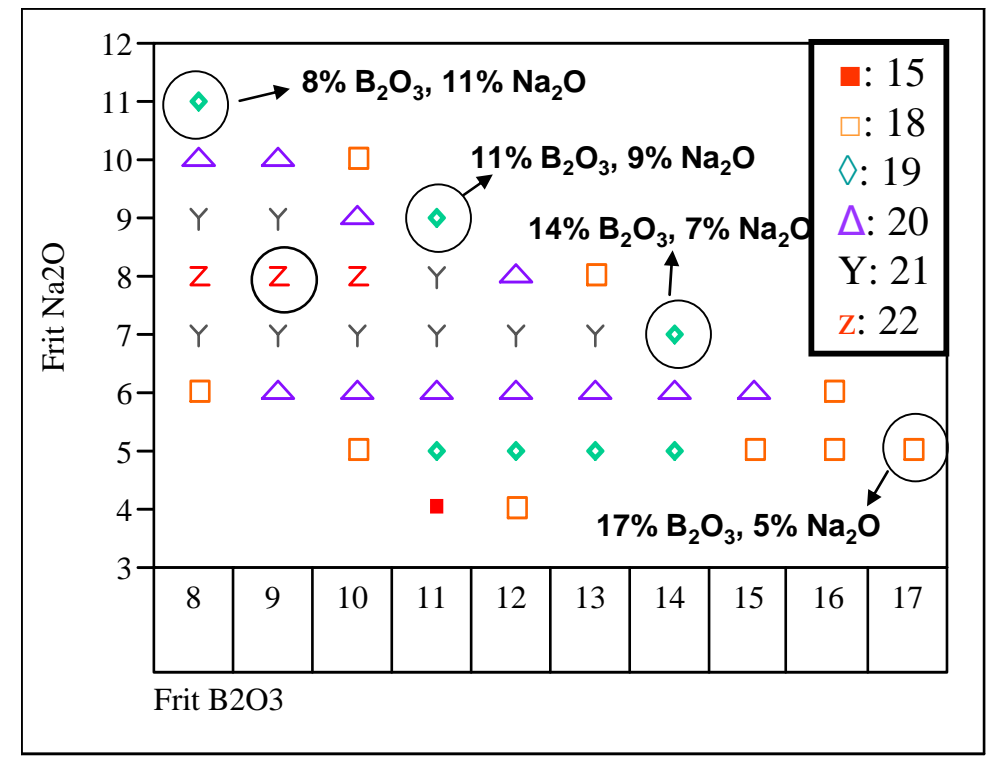

Figure 6-1. Candidate Frit Compositions for Cluster 2. 
WSRC-STI-2007-00688

Revision 0

Table 6-1. Candidate Frit Compositions for Cluster 2.

(oxide, wt $\%$ basis)

\begin{tabular}{||l|c|c|c|c|c||}
\hline \hline Oxide & SMR-1 & SMR-2 & SMR-3 & SMR-4 & SMR-5 \\
\hline $\mathrm{B}_{2} \mathrm{O}_{3}$ & 8 & 11 & 14 & 17 & 9 \\
\hline $\mathrm{Na}_{2} \mathrm{O}$ & 11 & 9 & 7 & 5 & 8 \\
\hline $\mathrm{Li}_{2} \mathrm{O}$ & 8 & 8 & 8 & 8 & 8 \\
\hline $\mathrm{SiO}_{2}$ & 73 & 72 & 71 & 70 & 75 \\
\hline \hline
\end{tabular}

The same strategy was used to identify candidate frits for Cluster 4 ("with" Al-dissolution). More specifically, Cluster 4 represents a lower $\mathrm{Al}_{2} \mathrm{O}_{3}$, higher $\mathrm{Fe}_{2} \mathrm{O}_{3}$ based sludge (similar to SB3) for which historical melt rate assessments suggest that one should target as high of a $\mathrm{Na}_{2} \mathrm{O}$ content as possible to achieve maximum melt rate. Even though higher $\mathrm{B}_{2} \mathrm{O}_{3}$ content did not influence the melt rate of SB3, this study will utilize the frits highlighted in Figure 6-2 to assess melt rate.

These frits have $\mathrm{Na}_{2} \mathrm{O}$ concentrations ranging from 4 to $8 \%$; with $\mathrm{B}_{2} \mathrm{O}_{3}$ contents ranging from 8 $14 \%$. Implementation of the same selection strategy will help to ensure, to the extent possible, that each flowsheet is given its best opportunity to demonstrate maximum waste throughputs. In addition to the four highlighted frits, the frit with $8 \% \mathrm{~B}_{2} \mathrm{O}_{3}$ and $6 \% \mathrm{Na}_{2} \mathrm{O}$ was selected, given it provides a maximum operating window width of 20 points. Table 6-2 summarizes the five candidate frits for Cluster 4. It is of particular interest that two of these five frits are Frit 418 and Frit 503. Frit 418 (high $\mathrm{Na}_{2} \mathrm{O}$, low $\mathrm{B}_{2} \mathrm{O}_{3}$ ) was used to process SB3 (a Purex based feed). Frit 503 (high $\mathrm{B}_{2} \mathrm{O}_{3}$, low $\mathrm{Na}_{2} \mathrm{O}$ ) was initially recommended for processing SB4 (HM based feed) prior to a decant decision whereby sodium was decreased, which led to a Frit $510\left(14 \% \mathrm{~B}_{2} \mathrm{O}_{3}\right.$ and $8 \%$ $\mathrm{Na}_{2} \mathrm{O}$ ) recommendation and ultimate implementation. Frit 510 is not a candidate for Cluster 4 based on the use of the 17 point operating window criteria.

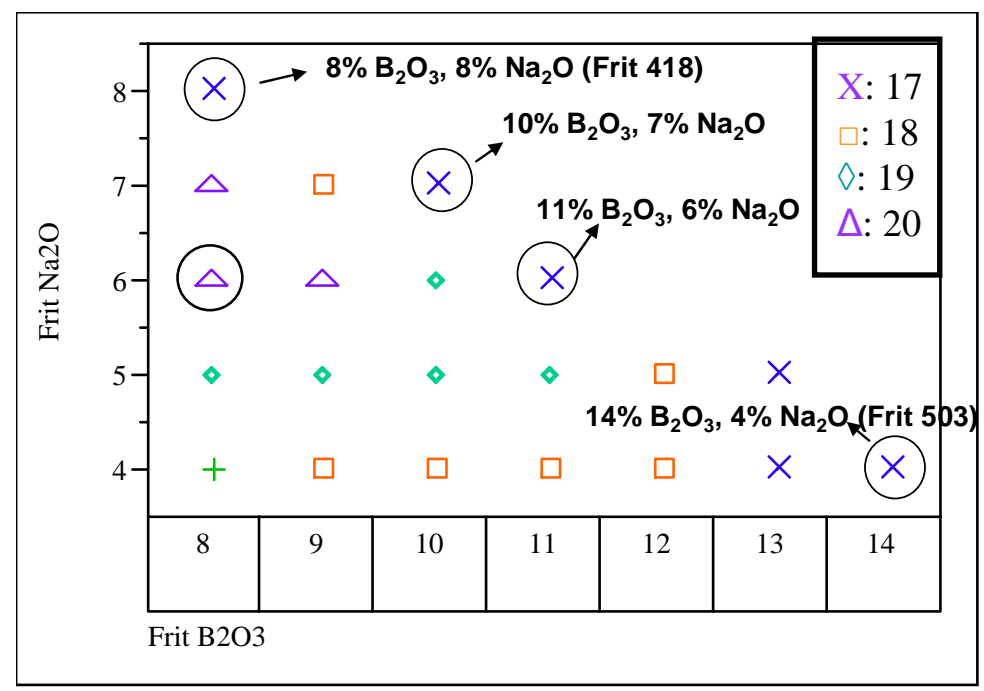

Figure 6-2. Candidate Frit Compositions for Cluster 4. 
WSRC-STI-2007-00688

Revision 0

Table 6-2. Candidate Frit Compositions for Cluster 4.

(oxide, wt\% basis)

\begin{tabular}{|l|c|c|c|c|c|}
\hline Oxide & SMR-6 & SMR-7 & SMR-8 & Frit 418 & Frit 503 \\
\hline $\mathrm{B}_{2} \mathrm{O}_{3}$ & 10 & 11 & 8 & 8 & 14 \\
\hline $\mathrm{Na}_{2} \mathrm{O}$ & 7 & 6 & 6 & 8 & 4 \\
\hline $\mathrm{Li}_{2} \mathrm{O}$ & 8 & 8 & 8 & 8 & 8 \\
\hline $\mathrm{SiO}_{2}$ & 75 & 75 & 78 & 72 & 74 \\
\hline
\end{tabular}

Although the use of historical trends is technically sound, there is a risk that one of the other frits shown in Figure 6-1 and Figure 6-2, but not selected, would yield the maximum waste throughput. Reaction paths associated with one of the intermediate compositional extremes may lead to the highest melt rate for one of the two flowsheet options. If true, decisions regarding the implementation of Al-dissolution may be biased. Although defined as a risk, the authors feel the risk is relatively low and the results obtained from the experimental portion of this program can be used in combination with actual DWPF processing data to provide valuable insight into the waste throughput potentials for both flowsheets. A higher programmatic risk is the assumption that the results obtained from the general "cluster" approach can be applied universally to future sludge batches. That is, one could envision the case in which the waste throughput versus mission life relationships may be sludge batch dependent. If true, then questions regarding the implementation of Al-dissolution may need to be evaluated and made on a case-by-case or sludge batch by sludge batch basis.

\subsection{Summary}

The objective of this study as part of the SMR program is to provide assessments of some of the downstream impacts, or lack thereof, of decisions regarding the implementation of Al-dissolution to support sludge mass reduction and processing. Based on future sludge batch compositional projections, assessments have been made with respect to the ability to maintain comparable projected operating windows for sludges with (based on high temperature dissolution) and without Al-dissolution. Twelve sludge batches were identified based on implementation of high temperature Al-dissolution while fourteen sludge batches represent the without Al-dissolution flowsheet. The assessments utilized two primary metrics to evaluate differences between the two flowsheet options: (1) the projected operating window size, defined as the waste loading interval over which glasses are classified as acceptable using current process control models, and (2) the number of frits that provide relatively large operating windows, which provides insight into the potential to adjust melt rate for a specific sludge batch.

In general, paper study assessments indicated that most of the future sludge batches, both with and without Al-dissolution, had multiple frits that were available that yielded relatively large operating windows. Using the 17-point width as a guide for "reasonable operating window size", there generally appeared to be more flexibility in frit selection for the without Al-dissolution flowsheets. This larger frit compositional platform could allow frit development efforts to make more significant adjustments to melt rate which ultimately could lead to a shorter mission life.

The paper study results did identify potential issues with $\sim 6$ flowsheets in terms of the projected operating window size. These flowsheets included: SB6 with and without Al-dissolution, SB8 
with Al-dissolution, SB15 with Al-dissolution, SB14 without Al-dissolution, and SB19 without Al-dissolution. The projected operating windows for these sludge batches were relatively small even with the large number of frits used in the evaluation. The results of these "problematic" sludge batches suggest that a different frit grid is required to obtain a reasonable projected operating window based on the current PCCS models and constraints or different blending and/or washing strategies should be considered for these sludge batches if higher WLs are required to meet processing expectations or contractual requirements.

Based on the general observations of the paper study assessments, and excluding the "problematic" sludge options discussed above, there is essentially no clear distinction between the two flowsheets based on the projected operating windows to drive an Al-dissolution decision. Comparable operating windows for both flowsheets can be achieved through the frit development and selection process. One could interpret this general statement to indicate: Given frit development efforts can compensate for the different pretreatment strategies yielding equivalent operating windows or maximum WL targets, the lower sludge mass as a result of Al-dissolution would obviously result in reducing the number of cans produced at DWPF. Although the authors agree that the basic mathematics to support that stance is technically sound, one needs to ask a couple of follow-on questions (at a minimum): Is a reduction in the sludge mass going to DWPF which should translate into a lower canister production count the only parameter of interest? What about facility operating times (mission life) for both tank farm and DWPF operations?

To address these questions, candidate frit compositions have been selected to assess melt rate as a function of waste loading for the glass systems representing the with and without $\mathrm{Al}$ dissolution flowsheets. A unique challenge for this task was the identification of a frit compositional region that would (1) provide the best opportunity to show the optimal operating windows for all future sludge batches and (2) ensure, to the extent possible, experimental assessments of melt rate for both with and without Al-dissolution are represented under the best possible conditions.

A second challenge was the shear number of sludges for which melt rate assessments were of interest. Although experimentally determining the waste loading versus melt rate trends for each of the 26 sludge batches provided by LWO would be of great value, time and budget constraints ultimately place restrictions on that possibility. Therefore, developing a defensible strategy that could be used to provide general insights into the advantages or impacts of Al-dissolution to overall mission life was paramount for this task. That is, how does one select a sludge option for each flowsheet that would result in the lowest waste throughput? Even if successful on that issue, how does one select the optimal frit to use in that melt rate assessment to provide each flowsheet with the best opportunity to show its optimal behavior?

The frit selection process was driven by reviewing compositional trends that have been seen historically to influence melt rate as well as identifying systems with relatively large operating windows. More specifically, increasing the $\mathrm{Na}_{2} \mathrm{O}$ content (typically used for PUREX or high $\mathrm{Fe}_{2} \mathrm{O}_{3}$ sludges - e.g., SB3) and increasing the boron and/or sodium content (typically used for $\mathrm{HM}$ or high $\mathrm{Al}_{2} \mathrm{O}_{3}$ sludges - e.g., SB4) are strategies that were pursued. With respect to the identification of sludge batches, average compositions representing with and without $\mathrm{Al}$ dissolution (referred to as "Clusters" in this report) were developed using a statistical grouping routine. Ultimately, five frits were identified for each cluster that utilize the historical trends in composition that have influenced melt rate in DWPF operations. For each cluster, melt rate assessments will be performed as a function of waste loading for the five frits selected. The data obtained from the experimental melt rate program can be used (in combination with actual DWPF processing data) to provide valuable insight into the waste throughput potentials for both 
flowsheets. The preparation of the simulants for melt rate testing provides an opportunity to assess CPC issues for the two flowsheets; which will be the subject of a separate report.

\subsection{Path Forward}

Melt rate assessments will be performed as a function of waste loading for the five frits selected for each cluster. Initially three WLs for each system will be targeted. The primary tool to be utilized will be the Melt Rate Furnace (MRF) at SRNL. This tool has proved invaluable during frit development efforts for SB3 and SB4 with respect to identifying frits that improved melt rate and in defining the WL or WL interval over which maximum waste throughputs could be achieved at DWPF. The MRF will be used to map the impacts of waste loading on melt rate in order to identify the waste loading where maximum throughput occurs for both Cluster 2 and Cluster 4 with the identified frits. The results will also provide insight into the frit that provides the maximum waste throughput for each cluster. In turn, this will allow comparisons of the compositional trends in frit with the historical trends observed when assessing melt rate impacts.

It should be noted that the MRF will utilize dried Sludge Receipt and Adjustment Tank (SRAT) product (targeting the nominal cluster compositions) coupled with a frit at a targeted waste loading. The MRF does not have the ability to assess liquid feeds and, thus, rheology impacts. Instead, the MRF is a "static" test bed in which a mass of dried melter feed (SRAT product plus frit) is placed in an "isothermal" furnace for a period of time to assess melt rate. These conditions, although historically effective in terms of identifying candidate frits for specific sludge batches and mapping out melt rate versus waste loading trends, do not allow for assessments of the potential impact of feed rheology on melt rate. That is, if the rheological properties of the slurried melter feed resulted in the mounding of the feed in the melter (i.e., the melter feed was thick and did not flow across the cold cap), melt rate and/or melter operations (i.e., surges) could be negatively impacted. Given the results of recent rheological measurements on SB4 and SB5, the possibility of this phenomenon exists. Once the primary frits for both Cluster \#2 and Cluster \#4 are determined via MRF testing, a decision regarding the need to perform Slurry Fed Melt Rate (SMRF) testing should be made to address this issue. However, this decision needs to factor in the ability to accurately represent rheological properties on unknown sludges since these physical properties can not currently be predicted.

\subsection{References}

1. Herman, C.C., Evaluation of LTAD Downstream Impacts - Status of SRNL 3L Tank 51 Sample Testing, 2007, SRNL-PSE-2007-00283.

2. Harbour, J.R., et al., Impact of Increased Aluminate Concentrations on Properties of Saltstone Mixes, 2007, WSRC-STI-2007-00506.

3. Fox, K.M. and D.K. Peeler, Demonstration of Very High Aluminum Retention in Simulated HLW Glass, 2007, SRNL-PSE-2007-00231.

4. $\quad$ Hay, M.S., et al., Characterization and Aluminum Dissolution Demonstration with a 3 Liter Tank 51H Sample, 2008, WSRC-STI-2007-00697.

5. $\quad$ Peeler, D.K., et al., Frit Development for High $\mathrm{Al}_{2} \mathrm{O}_{3}$ Based Sludge: Task Technical and Quality Assurance Plan, 2007, WSRC-STI-2007-00504. 
6. Brown, K.G., R.L. Postles, and T.B. Edwards, SME Acceptability Determination for DWPF Process Control, 2006, WSRC-TR-95-00364, Revision 5.

7. Koopman, D.C. and E.K. Hansen, A Summary of Rheology Data for SB3 and SB2/3 Blend Simulant Savannah River Site Wastes, 2004, WSRC-TR-2004-00116.

8. Gillam, J.M., H.B. Shah, and M.A. Rios-Armstrong, Sludge Batch Plan, 2005, CBU-PIT2005-00144.

9. Smith, M.E., T.M. Jones, and D.H. Miller, Sludge Batch 4 Baseline Melt Rate Furnace and Slurry-Fed Melt Rate Furnace Tests with Frits 418 and 510, 2007, WSRC-STI-200700450.

10. $J M P^{T M} .2005$, SAS Institute Inc.: Cary, NC. 
WSRC-STI-2007-00688

Revision 0

\section{Appendix A}

\section{Projected Sludges Batches With and Without \\ High Temperature Al-Dissolution and \\ Composition Information on Candidate Frits}


Table A1. Projected Compositions With High Temperature Al-Dissolution: SB6 - SB17

(source: SBP_R-2_6_19_07_WAD)

\begin{tabular}{|c|c|c|c|c|c|c|c|c|c|c|c|c|}
\hline Oxide & SB6 & SB7 & SB8 & SB9 & SB10 & SB11 & SB12 & SB13 & SB14 & SB15 & SB16 & SB17 \\
\hline $\mathrm{Al}_{2} \mathrm{O}_{3}$ & 22.827 & 18.228 & 13.449 & 12.577 & 11.945 & 13.564 & 17.461 & 16.577 & 15.648 & 13.044 & 13.663 & 13.810 \\
\hline $\mathrm{BaO}$ & 0.257 & 0.240 & 0.250 & 0.244 & 0.246 & 0.227 & 0.232 & 0.261 & 0.273 & 0.277 & 0.262 & 0.251 \\
\hline $\mathrm{CaO}$ & 1.909 & 2.896 & 2.959 & 3.391 & 3.659 & 3.510 & 3.652 & 3.405 & 3.243 & 2.905 & 2.950 & 2.935 \\
\hline $\mathrm{Ce}_{2} \mathrm{O}_{3}$ & 0.197 & 0.816 & 0.580 & 0.809 & 0.957 & 0.748 & 0.531 & 0.337 & 0.269 & 0.273 & 0.507 & 0.608 \\
\hline $\mathrm{Cr}_{2} \mathrm{O}_{3}$ & 0.312 & 0.255 & 0.311 & 0.297 & 0.291 & 0.365 & 0.374 & 0.401 & 0.407 & 0.382 & 0.330 & 0.301 \\
\hline $\mathrm{CuO}$ & 0.097 & 0.077 & 0.095 & 0.085 & 0.082 & 0.080 & 0.123 & 0.132 & 0.135 & 0.130 & 0.112 & 0.101 \\
\hline $\mathrm{Fe}_{2} \mathrm{O}_{3}$ & 25.744 & 37.353 & 33.829 & 38.049 & 40.684 & 41.223 & 36.186 & 31.258 & 29.653 & 29.492 & 33.970 & 35.534 \\
\hline $\mathrm{K}_{2} \mathrm{O}$ & 0.166 & 0.157 & 0.197 & 0.193 & 0.192 & 0.198 & 0.284 & 0.289 & 0.286 & 0.260 & 0.225 & 0.205 \\
\hline $\mathrm{La}_{2} \mathrm{O}_{3}$ & 0.074 & 0.261 & 0.209 & 0.273 & 0.314 & 0.257 & 0.217 & 0.164 & 0.145 & 0.141 & 0.198 & 0.221 \\
\hline $\mathrm{MgO}$ & 0.618 & 0.560 & 0.459 & 0.522 & 0.569 & 0.578 & 0.453 & 0.406 & 0.381 & 0.345 & 0.389 & 0.404 \\
\hline $\mathrm{MnO}$ & 8.788 & 6.887 & 10.664 & 8.243 & 6.693 & 3.812 & 4.259 & 3.153 & 2.681 & 2.934 & 2.391 & 2.094 \\
\hline $\mathrm{Na}_{2} \mathrm{O}$ & 19.910 & 20.314 & 20.620 & 21.289 & 21.410 & 21.712 & 21.879 & 21.452 & 21.177 & 21.216 & 21.017 & 20.624 \\
\hline $\mathrm{NiO}$ & 4.510 & 1.974 & 2.118 & 1.089 & 0.650 & 0.447 & 0.337 & 1.218 & 1.614 & 1.828 & 1.494 & 1.309 \\
\hline $\mathrm{PbO}$ & 0.087 & 0.338 & 0.247 & 0.332 & 0.389 & 0.295 & 0.251 & 0.170 & 0.143 & 0.148 & 0.236 & 0.274 \\
\hline $\mathrm{SO}_{4}$ & 1.878 & 0.607 & 0.510 & 0.288 & 0.158 & 0.108 & 0.090 & 0.151 & 0.176 & 0.231 & 0.198 & 0.183 \\
\hline $\mathrm{SiO}_{2}$ & 2.315 & 1.793 & 4.008 & 4.181 & 4.108 & 7.255 & 6.774 & 7.017 & 6.758 & 5.219 & 3.804 & 3.126 \\
\hline $\mathrm{ThO}_{2}$ & 1.208 & 0.642 & 3.117 & 3.077 & 3.086 & 1.253 & 0.538 & 0.201 & 0.089 & 0.031 & 0.012 & 0.005 \\
\hline $\mathrm{TiO}_{2}$ & 1.116 & 2.717 & 2.783 & 2.810 & 2.817 & 2.876 & 2.885 & 2.829 & 2.798 & 2.696 & 2.499 & 3.891 \\
\hline $\mathrm{U}_{3} \mathrm{O}_{8}$ & 7.460 & 3.250 & 2.910 & 1.537 & 1.013 & 0.630 & 2.571 & 9.726 & 13.293 & 17.656 & 14.993 & 13.400 \\
\hline $\mathrm{ZnO}$ & 0.143 & 0.081 & 0.117 & 0.084 & 0.068 & 0.243 & 0.238 & 0.215 & 0.210 & 0.206 & 0.162 & 0.140 \\
\hline $\mathrm{ZrO}_{2}$ & 0.384 & 0.557 & 0.568 & 0.627 & 0.668 & 0.618 & 0.666 & 0.639 & 0.622 & 0.585 & 0.589 & 0.583 \\
\hline
\end{tabular}


Table A2. Projected Compositions Without High Temperature Al-Dissolution: SB6 - SB19

(source: SBP_R-1_7_12_06_NAD)

\begin{tabular}{|c|c|c|c|c|c|c|c|c|c|c|c|c|c|c|}
\hline Oxide & SB6 & SB7 & SB8 & SB9 & SB10 & SB11 & SB12 & SB13 & SB14 & SB15 & SB16 & SB17 & SB18 & SB19 \\
\hline $\mathrm{Al}_{2} \mathrm{O}_{3}$ & 25.734 & 25.242 & 25.619 & 25.779 & 25.825 & 26.600 & 22.827 & 20.047 & 19.139 & 22.583 & 26.589 & 30.316 & 32.653 & 34.308 \\
\hline $\mathrm{BaO}$ & 0.230 & 0.206 & 0.196 & 0.192 & 0.191 & 0.160 & 0.190 & 0.219 & 0.273 & 0.245 & 0.200 & 0.183 & 0.180 & 0.183 \\
\hline $\mathrm{CaO}$ & 1.741 & 2.432 & 2.732 & 2.829 & 2.860 & 2.448 & 2.314 & 2.380 & 2.340 & 2.736 & 2.891 & 2.862 & 2.809 & 2.837 \\
\hline $\mathrm{Ce}_{2} \mathrm{O}_{3}$ & 0.120 & 0.529 & 0.723 & 0.787 & 0.807 & 0.677 & 0.540 & 0.325 & 0.208 & 0.245 & 0.640 & 0.407 & 0.258 & 0.196 \\
\hline $\mathrm{Cr}_{2} \mathrm{O}_{3}$ & 0.285 & 0.244 & 0.224 & 0.216 & 0.214 & 0.238 & 0.241 & 0.296 & 0.358 & 0.344 & 0.250 & 0.271 & 0.303 & 0.323 \\
\hline $\mathrm{CuO}$ & 0.071 & 0.066 & 0.063 & 0.062 & 0.062 & 0.051 & 0.071 & 0.093 & 0.100 & 0.135 & 0.089 & 0.117 & 0.095 & 0.085 \\
\hline $\mathrm{Fe}_{2} \mathrm{O}_{3}$ & 21.811 & 28.667 & 31.980 & 33.063 & 33.416 & 34.253 & 29.807 & 25.694 & 24.350 & 28.550 & 33.562 & 29.271 & 21.828 & 18.705 \\
\hline $\mathrm{K}_{2} \mathrm{O}$ & 0.238 & 0.192 & 0.167 & 0.159 & 0.156 & 0.130 & 0.151 & 0.189 & 0.187 & 0.271 & 0.196 & 0.258 & 0.226 & 0.213 \\
\hline $\mathrm{La}_{2} \mathrm{O}_{3}$ & 0.085 & 0.192 & 0.242 & 0.258 & 0.263 & 0.221 & 0.188 & 0.138 & 0.106 & 0.135 & 0.227 & 0.176 & 0.126 & 0.105 \\
\hline $\mathrm{MgO}$ & 0.863 & 0.584 & 0.496 & 0.468 & 0.460 & 0.430 & 0.355 & 0.322 & 0.347 & 0.273 & 0.383 & 0.280 & 0.337 & 0.375 \\
\hline $\mathrm{MnO}$ & 8.788 & 7.873 & 6.429 & 5.904 & 5.739 & 4.148 & 3.001 & 1.876 & 1.214 & 3.292 & 2.387 & 4.102 & 2.549 & 1.786 \\
\hline $\mathrm{Na}_{2} \mathrm{O}$ & 20.909 & 20.128 & 20.057 & 20.061 & 20.050 & 19.545 & 19.119 & 19.305 & 21.887 & 21.092 & 20.891 & 20.754 & 26.436 & 27.853 \\
\hline $\mathrm{NiO}$ & 3.942 & 1.900 & 0.970 & 0.664 & 0.569 & 0.360 & 0.810 & 1.244 & 2.697 & 1.665 & 0.560 & 0.172 & 0.260 & 0.319 \\
\hline $\mathrm{PbO}$ & 0.055 & 0.220 & 0.298 & 0.324 & 0.332 & 0.276 & 0.234 & 0.151 & 0.087 & 0.159 & 0.288 & 0.226 & 0.119 & 0.070 \\
\hline $\mathrm{SO}_{4}$ & 0.722 & 0.311 & 0.214 & 0.186 & 0.177 & 0.184 & 0.184 & 0.164 & 0.161 & 0.206 & 0.227 & 0.236 & 0.191 & 0.168 \\
\hline $\mathrm{SiO}_{2}$ & 3.569 & 3.075 & 2.710 & 2.584 & 2.544 & 3.729 & 2.748 & 4.112 & 5.192 & 4.064 & 2.980 & 3.514 & 6.631 & 8.271 \\
\hline $\mathrm{ThO}_{2}$ & 1.659 & 1.713 & 1.625 & 1.592 & 1.580 & 1.836 & 1.586 & 0.769 & 0.248 & 0.076 & 0.023 & 0.007 & 0.002 & 0.001 \\
\hline $\mathrm{TiO}_{2}$ & 2.517 & 3.043 & 3.198 & 3.245 & 3.259 & 3.353 & 3.263 & 3.256 & 3.209 & 3.314 & 3.194 & 2.145 & 2.729 & 3.096 \\
\hline $\mathrm{U}_{3} \mathrm{O}_{8}$ & 6.218 & 2.853 & 1.491 & 1.051 & 0.915 & 0.714 & 11.770 & 18.797 & 17.278 & 9.821 & 3.756 & 3.960 & 1.651 & 0.542 \\
\hline $\mathrm{ZnO}$ & 0.108 & 0.076 & 0.060 & 0.054 & 0.053 & 0.201 & 0.148 & 0.151 & 0.143 & 0.231 & 0.118 & 0.193 & 0.125 & 0.092 \\
\hline $\mathrm{ZrO}_{2}$ & 0.335 & 0.455 & 0.506 & 0.522 & 0.528 & 0.447 & 0.453 & 0.470 & 0.477 & 0.562 & 0.549 & 0.551 & 0.493 & 0.473 \\
\hline
\end{tabular}


Exhibit A1. Scatterplot Matrix of Cluster Compositions

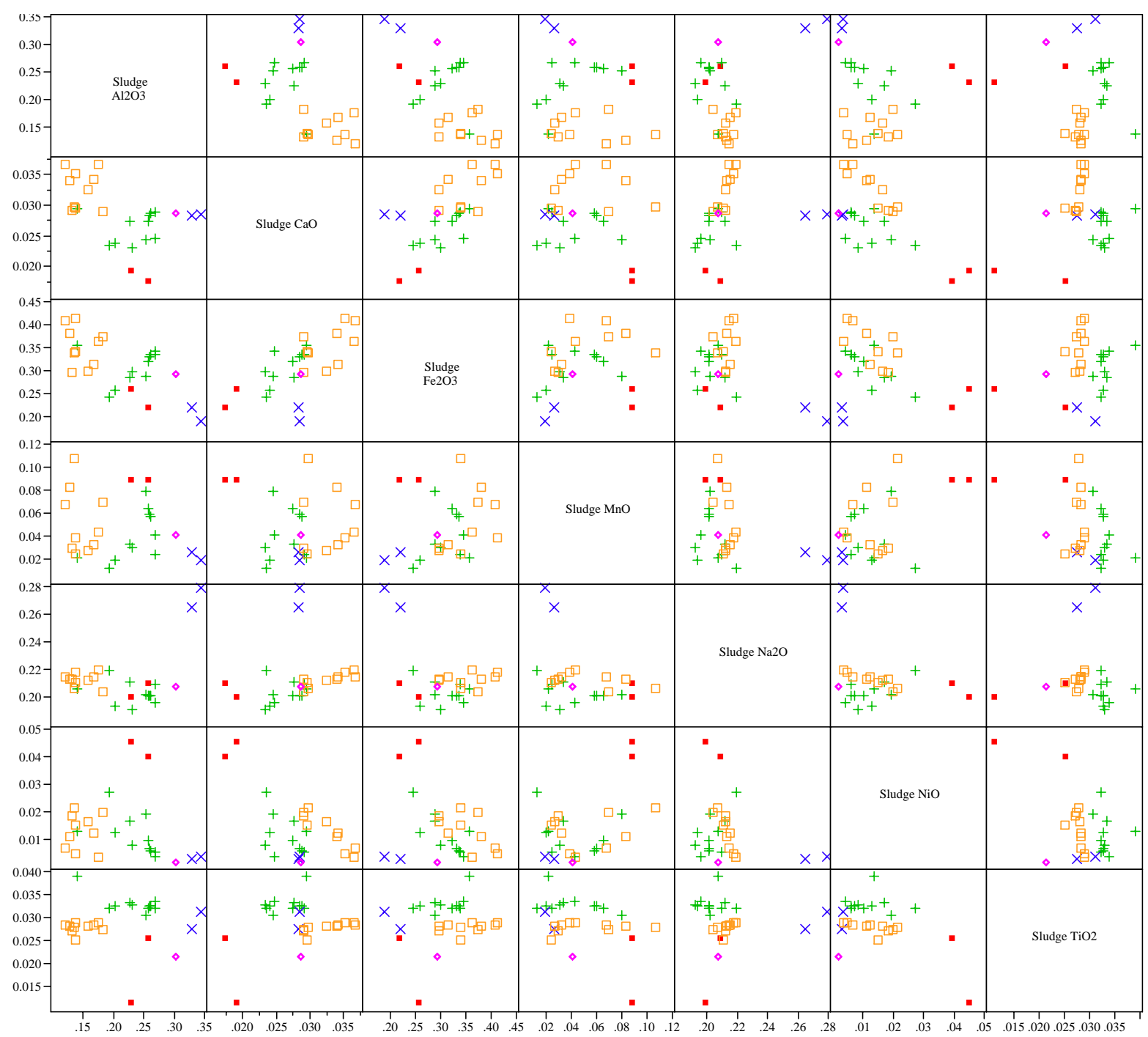


Exhibit A2. Cluster \#2 Average.

\section{Variability Chart for Operating Window Width by Frit Na2O within Frit B2O3}

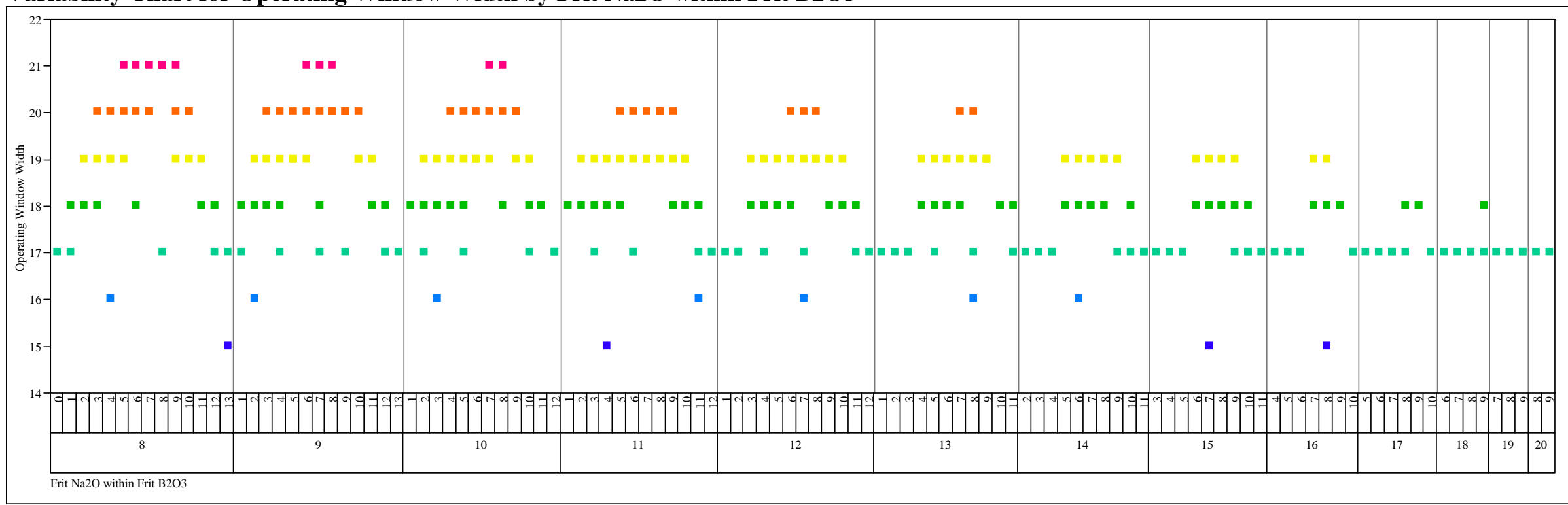


Exhibit A3. Cluster \#4 Average.

Variability Chart for Operating Window Width by Frit Na2O within Frit B2O3

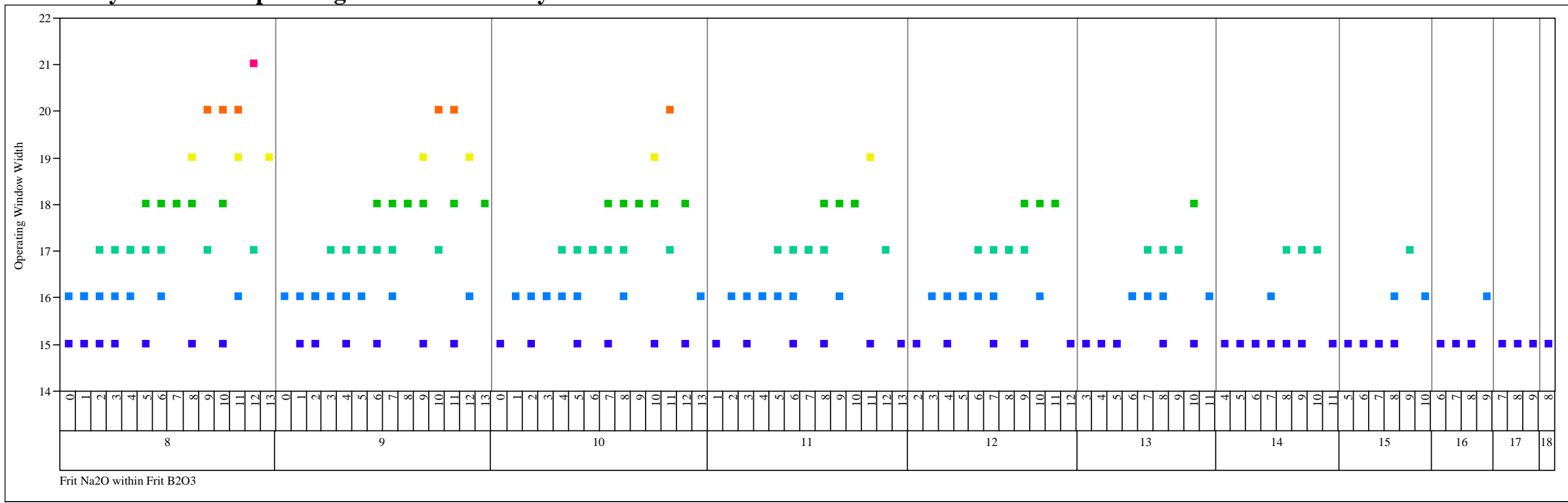


WSRC-STI-2007-00688

Revision 0

This page intentionally left blank. 


\section{Distribution:}

C.J. Bannochie, 773-42A

A.B. Barnes, 999-W

D.R. Best, 786-5A

D.B. Burns, 786-1A

D.A. Crowley, 999-W

B.A. Davis, 704-27S

R.E. Edwards, 773-A

T.B. Edwards, 999-W

K.M. Fox, 999-W

J.M. Gillam, 766-H

J.C. Griffin, 773-A

B.A. Hamm, 766-H

C.C. Herman, 999-W

P. J. Hill, 766-H

J.F. Iaukea, 704-30S

D.P. Lambert, 999-W

M.T. Keefer, 766-H

J.E. Marra, 773-A
D.J. McCabe, 773-42A

R.T. McNew, 704-27S

D.H. Miller, 999-W

T.A. Nance, 773-42A

J.E. Occhipinti, 704-S

D.K. Peeler, 999-W

B.R. Pickenheim, 999-W

J.A. Pike, 766-H

T.M. Punch, 766-H

F.C. Raszewski, 999-w

J.W. Ray, 704-S

H.B. Shah, 766-H

M.E. Smith, 999-W

M.E. Stone, 999-W

J. Stuberfield, 766-H

P.C. Suggs, 704-S

W.R. Wilmarth, 773-42A

A.L. Youchak, 999-W 